\title{
ENADE 2005: Perfil, desempenho e razão da opção dos estudantes pelas Licenciaturas
}

\author{
Márcia Regina F. de Brito ${ }^{1}$
}

Recebido em: 12/06/07

Avaliado em: 24/08/07

1 Professora titular, Faculdade de Educação, Unicamp.E-mail: mbrito@unicamp.br

Resumo: O Exame Nacional de Desempenho dos Estudantes (ENADE) é parte integrante do Sistema Nacional de Avaliação da Educação Superior e é composto da prova, do questionário de avaliação da prova, do questionário dos coordenadores e do questionário sócio-econômico com 114 questões. A partir da análise desse material e dos dados do Censo da Educação Superior, foi elaborado o presente estudo com a finalidade de analisar o perfil dos estudantes dos cursos de Licenciaturas que se submeteram ao ENADE 2005, o desempenho desses estudantes na parte de Formação Geral e as razões que apontam para a escolha de cursos de Licenciatura, além de se buscar estabelecer as relações entre algumas variáveis selecionadas procurando verificar quais as diferenças significativas. Os resultados mostraram que os estudantes de Licenciatura concentram-se em cursos noturnos de IES privadas e são oriundos predominantemente do ensino médio público; a principal razão para a escolha da Licenciatura é o desejo de ser professor. Com relação ao desempenho, os melhores resultados, tanto de ingressantes como concluintes, são da área de Física (questões objetivas) e Geografia (nas questões discursivas); quando foi feita a média de ingressantes e concluintes por área verificou-se que a menor média é a obtida pela área de Pedagogia e a maior pela Geografia.

Palavras-Chave: Avaliação da Educação Superior; Exame em Larga Escala, ENADE; Lienciaturas; Formação de Professores.

ENADE 2005: Profile, Performance and reasons for choosing teacher training programs.

Abstract: The Brazilian National Student Performance Exam (ENADE) is part of the National Higher Education Evaluation System and is composed of a test, a questionnaire evaluating the test, a questionnaire to be answered by the coordinators and a socio-economic questionnaire with 114 questions. The present study was elaborated from the analysis of this material and of the data from the Higher Education Census, with the purpose of analyzing the profile of the students of the teacher training programs that took the 2005 ENADE, their performance in the General Education portion of the test and the reasons they point out for choosing their programs. The study also tries to establish the relations between some selected variables in attempts to verify the significant differences. The results show that the students of the teacher training programs are concentrated in night classes of private higher education institutions and come mainly from public high schools. The main reason for their choice is the desire to become a teacher. In what concerns performance, the best results among freshmen as well as seniors, are in Physics (objective questions) and Geography (essay questions). The lowest mean of freshmen and seniors per area of knowledge is Pedagogy and the highest is Geography.

Key-words: Higher Education Evaluation; Large scale assessment; ENADE; Teacher Training; Teacher Education. 
A educação vem ocupando a pauta não só de congressos, seminários e encontros de educadores das mais diferentes formações, mas também da imprensa. Ao longo dos últimos anos e a partir da divulgação dos resultados dos exames de larga escala (SAEB, Prova Brasil, ENEM e ENADE), aplicados a estudantes dos vários níveis de ensino, houve um aumento na atenção dada ao desempenho e ao perfil dos estudantes brasileiros. As análises têm mostrado que vários fatores influenciam o desempenho dos alunos (dentre eles a escolaridade dos pais, nível sócio-econômico, localização da escola e outros), sendo que esses fatores de influência adquirem maior ou menor importância de acordo com o tipo de pesquisa que se desenvolve e os objetivos que se quer alcançar.

Um aspecto de fundamental importância para o entendimento dessa complexa malha de interrelações que compõe o sistema educacional é o papel desempenhado pelos professores na formação dos estudantes. A importância da formação dos professores vem sendo enfatizada desde a década de 1970 e congressos específicos e grupos de trabalho, nas várias áreas, têm contribuido para o avanço da discussão sobre esse tema. O professor exerce influência de várias maneiras, mas as pesquisas mostram que essas influências variam de intensidade e significância conforme a amostra e a variável enfatizada (BRITO, 1996).

De acordo com Popkewitz (1992), como existe atualmente a exigência de práticas de ensino que valorizem o pensamento crítico, a flexibilidade e a capacidade de questionar padrões sociais, torna-se indispensável que os futuros professores possuam entendimento sobre as relações estruturais nas quais o ensino e o currículo estão imersos.

É desejável que se desenvolva no professor habilidades e competências que o direcionem para a busca de uma cidadania ativa, consciente e participante. Dessa maneira, no exercício das atividades docentes, ele terá possibilidades de oferecer aos estudantes uma educação que os transforme em pensadores competentes, aptos a interpretar, analisar e compreender as transformações sociais. Deverá propiciar também instrumentos que possibilitem ao estudante interpretar e manipular as diferentes informações existentes.

De acordo com Coelho (2006, p. 51), os cursos de graduação que formam professores desempenham um papel de fundamental importância, pois formam pessoas que devem ser autônomas na busca do saber, que superem a mera competência técnica e o conhecimento que pode ser fácil e rapidamente reproduzido, buscando a formação integral do ser humano, formando licenciados com um espírito de constante interrogação a respeito do mundo, do homem, da cultura, da educação e da escola, ultrapassando o imediatamente dado e buscando ampliar a reflexão sobre o mundo. 
Isso coincide com o que pensa Nóvoa (1992, p. 26) quando afirma que o desenvolvimento de uma nova cultura profissional dos professores passa pela produção de saberes e de valores que dêem corpo a um exercício autônomo da profissão docente.

Estudos a respeito da formação de professores para as diferentes áreas e graus não são novos, no Brasil. Desde a década de setenta existe um forte movimento voltado para a melhoria e maior apoio governamental para os cursos de formação de Educadores. Isso pode ser verificado, por exemplo, nos Anais do Congresso Estadual Paulista de Formação de Educadores que vem sendo realizado desde o final da década de 1980 pela Universidade Estadual Paulista (UNESP).

Faria (1996), tratando da Licenciatura em Matemática, apontou alguns aspectos que são de grande importância para qualquer curso de Licenciatura em qualquer área. $\mathrm{O}$ autor verificou que raramente os cursos se organizam a partir da avaliação diagnóstica das reais necessidades e dificuldades pedagógicas dos professores em formação, sendo que poucas vezes os idealizadores dos cursos consideram outras dimensões do exercício profissional, como, por exemplo, o contexto institucional onde ocorrem, as condições de formação e os recursos disponíveis.

Porém, a avaliação no sistema universitário brasileiro é recente e ainda em fase de implantação. Embora em outros países a avaliação educacional tenha uma longa história de pesquisas e avanços, no Brasil ela aparece timidamente a partir da década de setenta. Até então a avaliação educacional era quase sempre limitada à avaliação dos estudantes através de provas e exames ou, em alguns casos, à avaliação dos professores pelos estudantes. A partir da década de noventa, a avaliação tornou-se um tema central nas discussões de professores e pesquisadores, sendo que, mais recentemente, tornou-se também objeto amplamente divulgado pelos meios de comunicação.

Hoje já temos disponíveis vários elementos que permitem a caracterização e traçado do perfil dos estudantes de graduação do Brasil. Essa possibilidade iniciou-se na década de noventa com o Exame Nacional de Estudantes ("Provão") e agora assumiu um caráter mais completo com o Exame Nacional de Desempenho dos Estudantes (ENADE). Assim, através dos resultados do questionário sócio-econômico, é possível traçar um perfil comparativo entre os vários cursos de Licenciatura, o desempenho dos estudantes tanto na parte de Formação Geral da prova e no componente específico, além de possibilitar que se conheça a razão pela qual os estudantes de graduação dos cursos de Licenciaturas que foram selecionados para a amostra e realizaram o exame optaram pela profissão de professor. 
Esses resultados permitem que os diferentes cursos de formação de professores se organizem levando em consideração os diferentes elementos que são apresentados pelos estudantes no questionário sócio-econômico e na prova. A formação de professores é um tópico de fundamental importância na pesquisa educacional porque é a partir da formação do professor que se inicia a construção de um ensino de qualidade, em qualquer um dos níveis. No ENADE, atendendo ao princípio de verificar a qualidade do ensino superior, foram inseridas, no questionário sócio-econômico, questões relativas às razões da opção pela licenciatura e outras questões que interessam diretamente aos estudantes de Licenciaturas e aos responsáveis pela formação de docentes para a educação fundamental e média.

Em estudos anteriores (BRITO, 1984, 1986; 1990; 1996; FINI; BRITO; CARVALHO, 1990), foi verificado que a opção pelos cursos de Licenciaturas, em IES onde se privilegia o Bacharelado, apresenta razões distintas daquelas dos alunos de cursos com alta demanda. Além disso, é comum a idéia de que os estudantes de Licenciaturas apresentam piores desempenhos que os estudantes de Bacharelado.

A idéia de que os estudantes de Bacharelado apresentam, em provas de desempenho acadêmico, resultados superiores aos estudantes das Licenciaturas não encontra suporte na literatura. Securro (1992) apresenta uma revisão de estudos a esse respeito em um artigo no qual descreve uma investigação realizada com a finalidade de avaliar as diferenças no desempenho acadêmico de Licenciados e Bacharéis. Esse autor acompanhou em um estudo longitudinal durante cinco anos, tendo como referência o GPA (Grade Point Average), as médias de desempenho de estudantes de bacharelado e licenciatura, tendo verificado que os resultados dos licenciandos foi igual ou melhor que o dos estudantes de Bacharelado.

A implantação do SINAES tem possibilitado que sejam desenvolvidos artigos, estudos, dissertações e teses (RISTOFF; GIOLO, 2006; LIMANA; BRITO, 2005; SOUSA, 2005; VENDRAMINI, 2005; BARREYRO, 2004; RISTOFF, 2003; DIAS SOBRINHO, 2002) que permitem compreender não apenas o sistema de avaliação da Educação Superior que vem sendo desenvolvido, mas também as definições, a concepção subjacente ao sistema, as análises que são feitas, os modelos de análise que podem ser usados, o que amplia e torna mais visível e compreensível as diferentes Instituições de Educação Superior, os diferentes cursos de graduação e as características e o perfil dos estudantes brasileiros. O ENADE propiciou o estudo do conjunto de estudantes de Licenciaturas e fornece um perfil das principais características desses futuros professores, permitindo que seja traçado um amplo panorama da formação de profissionais que atuarão no ensino fundamental e médio. 


\section{Objetivos do estudo}

O objetivo principal deste estudo consiste em traçar o perfil dos estudantes dos cursos de Licenciatura em Filosofia, Geografia, Letras, História, Pedagogia, Matemática, Física, Química, Ciências Sociais e Biologia que fizeram parte da amostra do ENADE 2005, verificando as principais razões da escolha da profissão de professor, relacionando as principais características dos estudantes com o desempenho na parte de formação geral da prova. Além disso, foram analisados o desempenho e as relações deste com algumas variáveis presentes no questionário sócio econômico. Assim, a análise dos dados utilizados na presente investigação, a respeito do perfil e da razão da opção dos estudantes pelos cursos de Licenciaturas, foi elaborada com os seguintes objetivos:

(1) Comparar os dados obtidos através do questionário sócio-econômico do ENADE com as informações do Censo da Educação Superior 2004, observando a relação candidato/vaga, número de estudantes inscritos no vestibular e número de ingressantes, número de concluintes de acordo com a organização acadêmica e a região onde se encontra a IES;

(2) Explorar as principais características sócio-econômicas dos estudantes dos cursos de licenciatura que participaram do ENADE 2005, buscando traçar um perfil daqueles que optam por esses cursos.

(3) Relacionar as relações entre as razões da opção pelo magistério e o desempenho no ENADE 2005.

\section{Material utilizado}

Questionário sócio econômico: Desde a vigência do Exame Nacional de Cursos (ENC-antigo "Provão") era aplicado um amplo questionário, com 103 questões, a todos os estudantes concluintes dos cursos avaliados. A partir de 2004, com a substituição do antigo exame pelo Exame Nacional de Desempenho dos Estudantes, manteve-se o questionário sócio-econômico, e foram feitas uma revisão do enunciado das questões e a inclusão de outras. Em 2005, foram introduzidas algumas questões a respeito das razões da opção pelo curso de Licenciaturas. O questionário sócio-econômico, na versão utilizada atualmente, pode ser encontrado no seguinte endereço eletrônico: http://www.inep.gov.br/download/enade/ 2006/QS.pdf

Base de dados do Exame Nacional de Desempenho dos Estudantes: A base de dados foi trabalhada a partir dos microdados disponibilizados 
pelo INEP. Para as análises foi utilizado o programa SPSS. A construção da base de dados foi feita a partir da base de dados geral de onde foram extraídas informações do questionário sócio-econômico, dos resultados do exame (nota bruta e ponderada) deste total de estudantes de Bacharelado e Licenciatura apresentado na tabela 1, das áreas de Filosofia, Geografia, Letras, História, Pedagogia, Matemática, Física, Química, Ciências Sociais e Biologia. A partir do questionário sócio-econômico, foram analisadas as cinco questões respondidas apenas pelos estudantes de Licenciaturas (ingressantes e concluintes) relativas às razões da escolha de carreira do Magistério, percepção da validade e utilidade das disciplinas pedagógicas, dentre outras.

Inicialmente, no banco de dados geral (incluindo todos os estudantes que participaram do ENADE2005), constavam 387.971 estudantes, sendo $52,6 \%$ do gênero feminino e, destes, 168.795 eram concluintes e 219.176 ingressantes, distribuídos em 32 áreas de conhecimento, sendo a maior concentração no curso de Pedagogia (15,8\%), seguida de Computação $(15,5 \%)$. Na base original do ENADE 2005, aparecem também os estudantes de áreas do ENADE 2004 que, por razões diversas, não compareceram ao exame em 2004 e foram autorizados pela comissão especial que analisa esses casos a realizar o exame em 2005. Deve ser destacado que esses estudantes não entram em nenhuma análise e fazem apenas a parte de formação geral.

No presente estudo, o critério de filtragem foi o sujeito ser estudante de Licenciatura, ter sido selecionado e apresentado, pelo menos, alguma resposta frente à prova. Após a filtragem, foi obtido o total de 286.710 sujeitos, sendo que destes, 640 são estudantes voluntários. Como a proposta do presente trabalho é estudar o perfil dos professores em formação e a razão entre a opção pelo magistério e o desempenho no ENADE (2005), cabe apresentar os dados relativos aos cursos selecionados para este estudo.

Foi adotado o nível de significância 0,05 para as análises estatísticas, sendo consideradas diferenças altamente significativas quando a significância do teste $p<0,001$, muito significativas quando $0,01<p \mathrm{~d}$ 0,001 e pouco significativa quando $0,05<p \mathrm{~d} 0,01$. Para valores $p$ superiores e bem próximos de 0,05 as diferenças são consideradas marginalmente significativas. As distribuições do número de estudantes de acordo com cada variável estudada são apresentadas por carreira, em valores absolutos $\left(\mathrm{N}^{\circ}\right)$, valores percentuais em relação ao total de alunos de cada área $(\%)$ e valores percentuais em relação ao total de alunos que não deixaram em branco a questão em análise (\% válida). 
Dados do Censo da Educação Superior: Disponibilizados pelo INEP. A partir dos dados do Censo 2004 e 2005, foram verificados o número de cursos de Licenciaturas, distribuição por região, por categoria administrativa, relação candidato-vaga, número de ingressantes e concluintes além de outros elementos que compõem um estudo mais detalhado de cada uma das Licenciaturas, em fase de elaboração.

\section{Alguns dados iniciais sobre a Formação de Professores}

Os cursos de formação de professores não têm recebido a merecida atenção. Ao longo dos anos, essa profissão foi gradativamente sendo sucateada, particularmente em função da idéia amplamente disseminada de que formar bacharéis, futuros pesquisadores, se reveste de uma importância maior que formar professores. O Censo da Educação Superior permite a construção de séries históricas onde pode ser observado o comportamento desses cursos, o número de vagas, de matrículas, de egressos, por região, etc. A figura 1 permite verificar que a década de noventa foi aquela onde o número de estudantes era bastante reduzido e, gradativamente, vai aparecendo um incremento, sendo que em 2004 o número de estudantes ultrapassa a barreira dos 100.000. Porém, o número de professores que concluem as Licenciaturas ainda é bastante baixo e algumas delas são bastante deficitárias no número de matrículas.

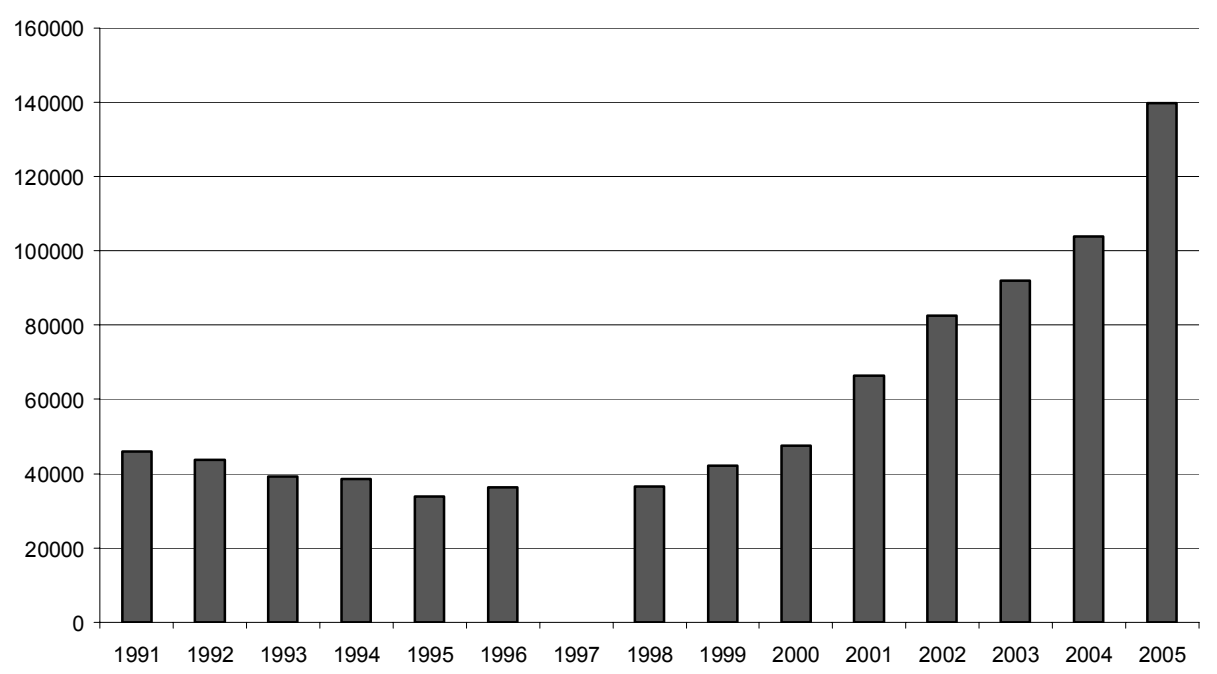

Figura 1 - Distribuição do número de estudantes de Licenciaturas.

Fonte: DEAES/INEP/MEC (Censo2005) 
O Exame Nacional de Desempenho dos Estudantes (ENADE) no ano de 2005 avaliou ingressantes e concluintes dos seguintes cursos de Licenciaturas: Letras, Ciências Biológicas, História, Matemática, Geografia, Artes, Física, Filosofia e Química, além do curso de Pedagogia que forma professores da Educação Infantil e das séries iniciais ( $1^{\underline{a}}$ a $4^{\underline{a}}$ séries) do Ensino Fundamental. A Escola Normal Superior não foi avaliada neste ano porque possui características marcadamente distintas do curso de Pedagogia e seus estudantes foram avaliados em 2005. Os estudantes de Licenciatura em Educação Física foram avaliados juntamente com a área de Saúde em 2004 e, nessa ocasião, o questionário sócio-econômico ainda não continha as questões referentes à opção profissional pela Licenciatura.

De acordo com o relatório preliminar do ENADE 2005, o número de estudantes de cursos que incluem Bacharelado e Licenciatura foi o seguinte:

Tabela 1: ENADE 2005: Relatório preliminar de presença por área em cursos com Licenciaturas (Inclui Bacharelado e Licenciatura).

\begin{tabular}{|l|c|r|r|}
\hline \multicolumn{1}{|c|}{ Área } & $\begin{array}{c}\text { Inscritos e } \\
\text { Incluídos }\end{array}$ & Presentes & \multicolumn{1}{c|}{$\begin{array}{c}\% \\
\text { Presenças }\end{array}$} \\
\hline Biologia & 28.565 & 25.343 & 88,72 \\
\hline Ciências Sociais & 5.314 & 3.977 & 74,84 \\
\hline Filosofia & 5.985 & 4.745 & 79,28 \\
\hline Física & 5.744 & 4.441 & 77,32 \\
\hline Geografia & 14.932 & 12.847 & 86,04 \\
\hline História & 22.912 & 19.322 & 84,33 \\
\hline Letras & 55.977 & 49.075 & 87,67 \\
\hline Matemática & 24.690 & 20.300 & 82,22 \\
\hline Pedagogia & 61.214 & 54.741 & 89,43 \\
\hline Química & 8.572 & 7.447 & 86,88 \\
\hline
\end{tabular}

Fonte: DEAES/INEP/MEC (2005). 


\section{Seleção da amostra do presente estudo}

O critério de seleção dos sujeitos que compõem a base de dados utilizada no presente estudo foi o estudante de Licenciatura ter respondido a pelo menos uma das partes da prova de Formação Geral. Com isso verificou-se que, na parte discursiva, 7,2\% dos estudantes deixaram a prova em branco, enquanto que na parte objetiva apenas $0,4 \%$ dos estudantes deixaram todas as questões em branco, mostrando que mais estudantes deixaram em branco a parte discursiva dessa prova. Assim como na prova de Formação Geral, na parte da prova referente ao Componente Específico, observou-se a preferência pelas questões objetivas, em relação às questões discursivas. Foi constatado que, do total, 39.693 sujeitos $(21,5 \%)$ não responderam nenhuma questão discursiva na parte do componente específico e $658(0,4 \%)$ não responderam nenhuma questão objetiva. 144.781 estudantes $(78,5 \%)$ responderam a parte discursiva, enquanto $183.813(99,6 \%)$ dos que participaram do ENADE 2005 responderam a parte objetiva, indicando a preferência pelas questões objetivas também no componente específico da prova.

\section{Análise Descritiva das variáveis sócio-econômicas das carreiras de magistério que participaram do ENADE 2005}

As análises apresentadas a seguir se referem às variáveis observadas no questionário sócio-econômico, principalmente em relação às cinco questões respondidas pelos estudantes das áreas de Licenciatura. Os resultados de cada carreira são comentados em relação à porcentagem válida de estudantes, não considerando as respostas deixadas em branco.

Considerando que esse relatório tem a finalidade de dar subsídios às IES para analisar como se caracterizam as carreiras de magistério avaliadas no ENADE 2005, sem, no entanto, analisar cursos e instituições isoladamente, optou-se por excluir da análise as variáveis que de alguma forma pudessem identificar as IES participantes do exame.

As distribuições do número de estudantes de acordo com cada variável estudada são apresentadas primeiramente no geral e, a seguir, por carreira, em valores absolutos $\left(\mathrm{N}^{\circ}\right)$, valores percentuais em relação ao total de estudantes de cada área (\%) e valores percentuais em relação ao total de estudantes que não deixaram em branco a questão em análise (\% válida). 
Também são usadas tabelas cruzadas, a fim de descrever, de forma sumarizada, a distribuição das freqüências em categorias ou grupos de uma segunda variável sem um fim inferencial. Desta forma, o ponto fundamental não é fazer comparações explícitas generalizadas para populações maiores, mas sim prover uma informação sumarizada descrevendo os grupos. Além disso, essas tabelas cruzadas são usadas em estudos de pesquisa com o objetivo de tirar conclusões sobre as relações presentes, na população, com base em dados de uma amostra.

Do total de participantes do ENADE 2005, após a filtragem $(N=$ 286.710), foram separados para análise os estudantes de 10 carreiras de magistério, como mostrado na Tabela 10. Observa-se que a carreira com maior número de participantes é a Pedagogia (27,3\%), seguida de Letras (24,6\%). Esses dados são coerentes com o Censo de 2004 em que o curso de Pedagogia aparece como a área de conhecimento que abarca a maior parte dos estudantes, tanto concluintes quanto ingressantes, em todas as regiões do país.

Considerando que o objetivo do presente estudo é investigar aspectos relativos aos estudantes de Licenciaturas, isto é, o perfil dos mesmos, a opção pelo magistério e o desempenho no ENADE 2005, todos os estudantes de Bacharelado foram excluídos da base de dados, tendo sido obtido um grupo de 184.474 estudantes distribuídos entre as 10 carreiras que participaram do ENADE 2005.

Assim, a amostra abrange apenas os estudantes de Licenciaturas e, deste total $(\mathrm{n}=184.474)$ foi verificado que $92.358(50,1 \%)$ são concluintes e $92.116(49,9 \%)$ são ingressantes. A idade informada por esses estudantes variou de 16 a 88 anos ( $M=28$ anos; $D P=8,5$ anos), sendo que $68 \%$ desses estudantes apresentam idades entre 20 e 34 anos e, destes, 34,3\% têm entre 20 a 24 anos. Foi verificado também que 54,2\% desses estudantes de Licenciatura se encontram matriculados no período noturno e apenas $6,2 \%$ freqüentam cursos com período integral, valendo observar que esta questão deixou de ser respondida por $20,6 \%$ dos estudantes que compuseram a amostra.

Com relação ao gênero, verificou-se que $73,7 \%$ pertencem ao gênero feminino $(N=135.903)$ e 26,3\% são do gênero masculino, representando mais que o dobro do número de homens e confirmando a predominância das mulheres atuando como professoras. No que se refere à etnia, 60,8\% dos estudantes se declararam brancos (cerca de $29,4 \%$ se declaram mulatos/pardos, $1,3 \%$ de origem oriental e 1,2\% indígena. 


\section{Onde estão os estudantes das Licenciaturas?}

Confirmando os dados disponíveis sobre a Educação Superior Brasileira, a região Sudeste é a que detém o maior número de matrículas dos estudantes de Licenciaturas participantes do ENADE 2005. Isso ocorre em todas as dez áreas do conhecimento avaliadas, dado que esta região é a que apresenta maior número de IES. Foi constatado que 44,8\% das matrículas são na região Sudeste. O segundo maior número de matrículas se concentra nas regiões Nordeste e Sul, sendo o Norte a região com o menor número de matrículas. $(5,8 \%)$. Estes resultados podem ser observados na Figura 2.

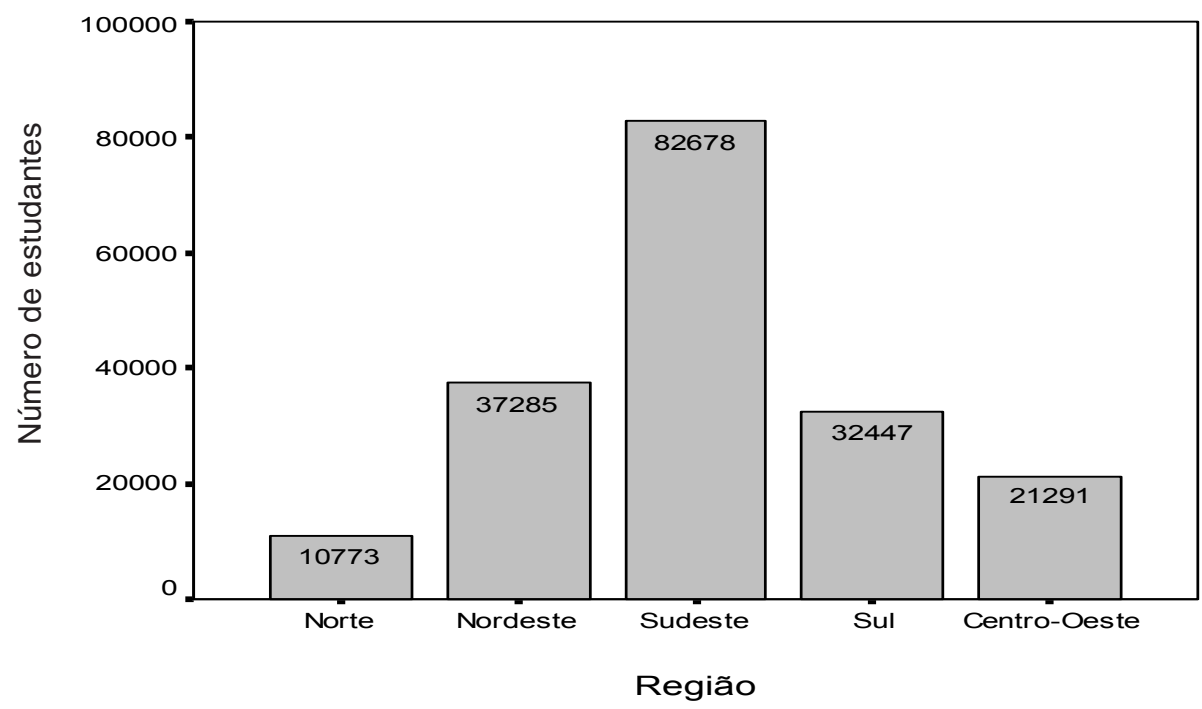

Figura 2 - Distribuição do número de estudantes de Licenciaturas de acordo com a região do país

A distribuição dos estudantes agrupados de acordo com a organização acadêmica das IES mostra que mais da metade dos estudantes $(57,7 \%)$ estão em Universidades, enquanto as demais se distribuem entre Faculdades, Escolas e Institutos Superiores $(20,6 \%)$ e outras organizações acadêmicas. Observa-se que os Centros de Educação Tecnológica apresentam a menor quantidade de estudantes $(0,3 \%)$.

Deve-se considerar que os Centros de Educação Tecnológica são em número reduzido no país, portanto, também é pequeno o número de participantes desta organização acadêmica relativamente ao total de participantes do ENADE 2005. Deve-se também observar que a prevalência da 
Universidade frente às demais organizações acadêmicas é equivalente aos dados do Censo 2004 (fonte DEAES/INEP/MEC), referente à distribuição do número de estudantes ingressantes e concluintes, de acordo com a área de conhecimento e organização acadêmica.

Foi verificado que a distribuição de estudantes por região depende da organização acadêmica da IES. A Universidade é a organização predominante em todas as regiões do país $(57,7 \%)$, seguida da organização de Faculdades, Escolas e Instituições Superiores (20,6\%). Verifica-se que os Centros de Educação Tecnológica não aparecem na região Sul do país para as Licenciaturas que compõem este estudo. Existe diferença significativa de distribuição dos estudantes por região, quando são agrupados de acordo com a organização acadêmica $\left(\square^{2}[16]=17746,239 ; p<0,001\right)$. Cabe destacar que esses dados são bastante semelhantes às informações do Censo de 2004, em que a Universidade também aparece como a organização acadêmica com maior número de estudantes, ingressantes e concluintes, de acordo com a área de conhecimento, região e organização acadêmica.

A distribuição de estudantes de acordo com a categoria administrativa da instituição mostra a grande concentração de estudantes de IES privadas, cuja freqüência é 113.562 , representando $61,6 \%$ dos estudantes, enquanto $38,4 \%$ estão em IES federais, estaduais e municipais.

De acordo com esses os resultados obtidos, verificamos que, independente da região, são as Universidades que possuem o maior número de cursos e estudantes de Licenciaturas, sendo que, do total, $61,6 \%$ se concentram em instituições privadas.

\section{Desempenho dos estudantes de Licenciaturas na parte de Formação Geral}

O SINAES tem como objetivo específico avaliar as Instituições, os cursos e o desempenho dos estudantes. Nesta perspectiva, o ENADE tem o objetivo de verificar as competências e habilidades básicas das áreas, os conhecimentos sobre conteúdos básicos e profissionalizantes e, ainda, verificar o desempenho em questões transdisciplinares, envolvendo o conhecimento mais geral. O exame tem aplicação trienal, por grupos de áreas, sendo que os estudates são selecionados pelo INEP por amostragem aleatória, incluindo estudantes do início (ingressantes) e do final dos cursos (concluintes). O exame é composto de um questionário sócio-econômico enviado peviamente para a residência do estudante, respondido e devolvido na hora da prova, a prova propriamente dita e as questões de avaliação da prova respondidas ao término da mesma. 
ENADE 2005: Perfil, desempenho e razão da opção dos estudantes pelas Licenciaturas

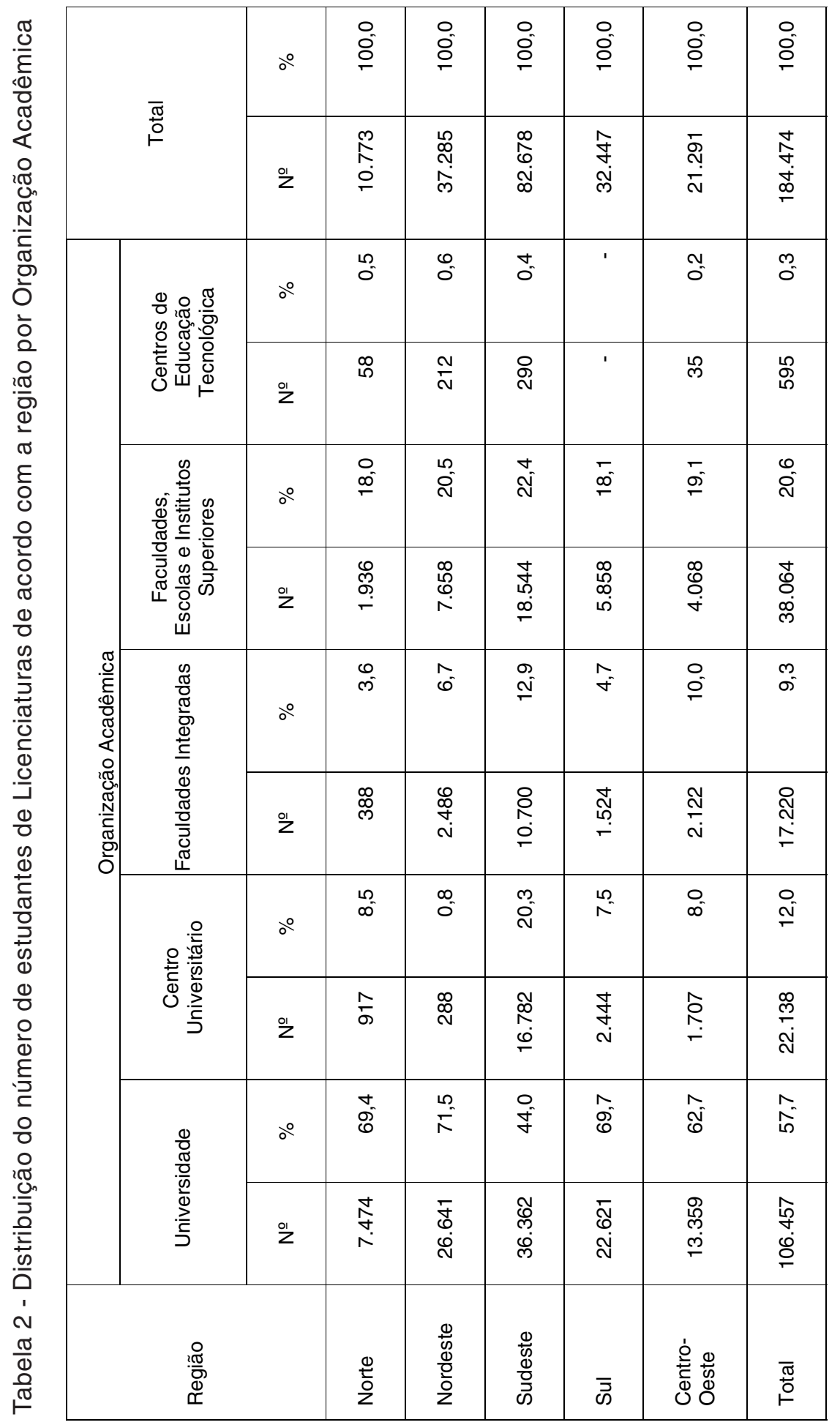


A prova é composta de 40 (quarenta) questões, sendo 10 questões de formação geral, comum a todas as áreas e 30 (trinta) questões do componente específico. As questões podem ser de múltipla escolha e discursivas, tanto na parte comum quanto na parte específica da área. As questões são elaboradas em forma de estudos de caso, situações e alternativas problematizadoras, dentre outras. Com relação ao grau de dificuldade, as questões devem distribuir-se entre questões com grau baixo de dificuldade, grau médio de dificuldade e grau elevado de dificuldade.

A parte de formação geral da prova do ENADE é composta de dez questões comuns a todas as áreas e respondida por todos os estudantes sendo, portanto, a única parte que permite comparação do desempenho dos estudantes dos diferentes cursos. A Tabela 3 apresenta a nota bruta dos estudantes na parte de formação geral. As notas estão colocadas em ordem decrescente, permitindo a comparação das médias obtidas pelos estudantes dos diversos cursos de Licenciaturas e em quais deles os estudantes se sairam melhor na parte de Formação Geral. Comparando esta tabela àquela publicada no Resumo Técnico 2005, pode-se verificar um incremento na média dos cursos. Isto ocorre porque no presente trabalho são considerados apenas os estudantes que responderam pelo menos uma questão da parte de formação geral, enquanto no resumo são considerados todos os estudantes presentes.

Tabela 3 - Licenciaturas: Estatísticas descritivas da nota bruta na formação geral por carreiras

\begin{tabular}{lrrrrc}
\hline Curso & $\begin{array}{c}\text { № de } \\
\text { estudantes }\end{array}$ & Mínimo & Máximo & Média & Desvio-padrão \\
\hline Geografia & 12.099 & 0,0 & 100,0 & 62,47 & 17,64 \\
Física & 3.582 & 0,0 & 100,0 & 58,55 & 18,42 \\
Letras & 44.463 & 0,0 & 100,0 & 58,09 & 16,63 \\
Biologia & 20.582 & 0,0 & 100,0 & 58,08 & 16,50 \\
Filosofia & 4.520 & 0,0 & 97,8 & 57,78 & 18,01 \\
História & 17.983 & 0,0 & 100,0 & 56,97 & 17,67 \\
Matemática & 18.701 & 0,0 & 97,0 & 55,25 & 16,68 \\
Ciências Sociais & 3.475 & 0,0 & 97,8 & 54,35 & 25,07 \\
Química & 5.698 & 0,0 & 97,0 & 53,95 & 16,73 \\
Pedagogia & 53.357 & 0,0 & 98,5 & 50,28 & 15,04 \\
\hline Total & 184.460 & 0,0 & 100,0 & 55,52 & 17,06 \\
\hline
\end{tabular}


O melhor resultado foi obtido pelos estudantes do curso de Licenciatura em Geografia, seguidos bem de perto de Física e Letras. A análise de variância apontou diferenças significativas entre as médias dos grupos $(p<0,001)$. Nesta parte de formação geral, pode-se perceber que as médias obtidas a partir das notas brutas apresentaram-se superiores a $50 \mathrm{em}$ todas as carreiras, sendo que o curso de Pedagogia apresentou a menor média do grupo. Embora as médias dos estudantes dos cursos de Licenciaturas tenham sido superior a 50, a média de todos os estudantes, nesta primeira parte foi 55,52. Considerando o resultado geral, essas médias estão bastante baixas, pois nenhum ultrapassou média 70. Além disso, pode ser verificado que nos cursos de Licenciatura em Matemática, Química, Pedagogia, Ciências Sociais e Filosofia, nenhum estudante obteve nota bruta superior a 98,5 .

Considerando que o objetivo da parte de Formação Geral da prova é avaliar o desenvolvimento de conhecimentos úteis para se atingir objetivos valorizados pela cultura, mas cuja aquisição independe de disciplinas específicas, e que as questões não são de conhecimentos gerais, mas se referem à formação geral (RISTOFF; GIOLO, 2006; LIMANA; BRITO, 2005) e tratam de temas como biodiversidade, ética, leitura de gráficos, artes etc. é importante assinalar para as IES a necessidade de maior atenção à formação geral, pois é extremamente relevante que o futuro professor não seja apenas um transmisssor de conhecimentos sobre objetos da ciência, mas sim um profissional competente na formação de bons pensadores, aptos a refletir e compreender o mundo (BRITO, 1996; COELHO, 2006; NÓVOA, 1992; MARTINEZ, 2000; DIAS SOBRINHO, 2005).

\section{Perfil do estudante de Licenciatura participante do ENADE 2005}

Do total de participantes dos cursos de Licenciatiuras do ENADE 2005, verifica-se que $63,7 \%(N=94.428)$ declaram-se solteiros, 57,0\% moram com os pais $(N=84.321)$ e $67,9 \%$ estudam no período noturno $(\mathrm{N}=99.918)$. Em relação à faixa de renda mensal da família, 50,3\% têm a renda de 3 a 10 salários mínimos $(N=74.714)$ e a maior parte dos estudantes $(84,5 \%)$ que responderam pelo menos uma das partes da prova, trabalham, sendo que apenas $15,5 \%$ declararam que apenas estudam. $48 \%$ dos estudantes desta amostra concluíram o segundo grau entre os anos 2000-2004 e 38,9\% concluíram o segundo grau na década de noventa, sendo que $68,2 \%$ o fizeram em escolas públicas. Quando se verifica o tipo de ensino médio que o futuro professor concluiu verificamos que $52 \%$ cursaram o ensino médio comum ou de educação geral, no ensino regular; $26,9 \%$ concluíram o cur- 
Márcia Regina F. de Brito

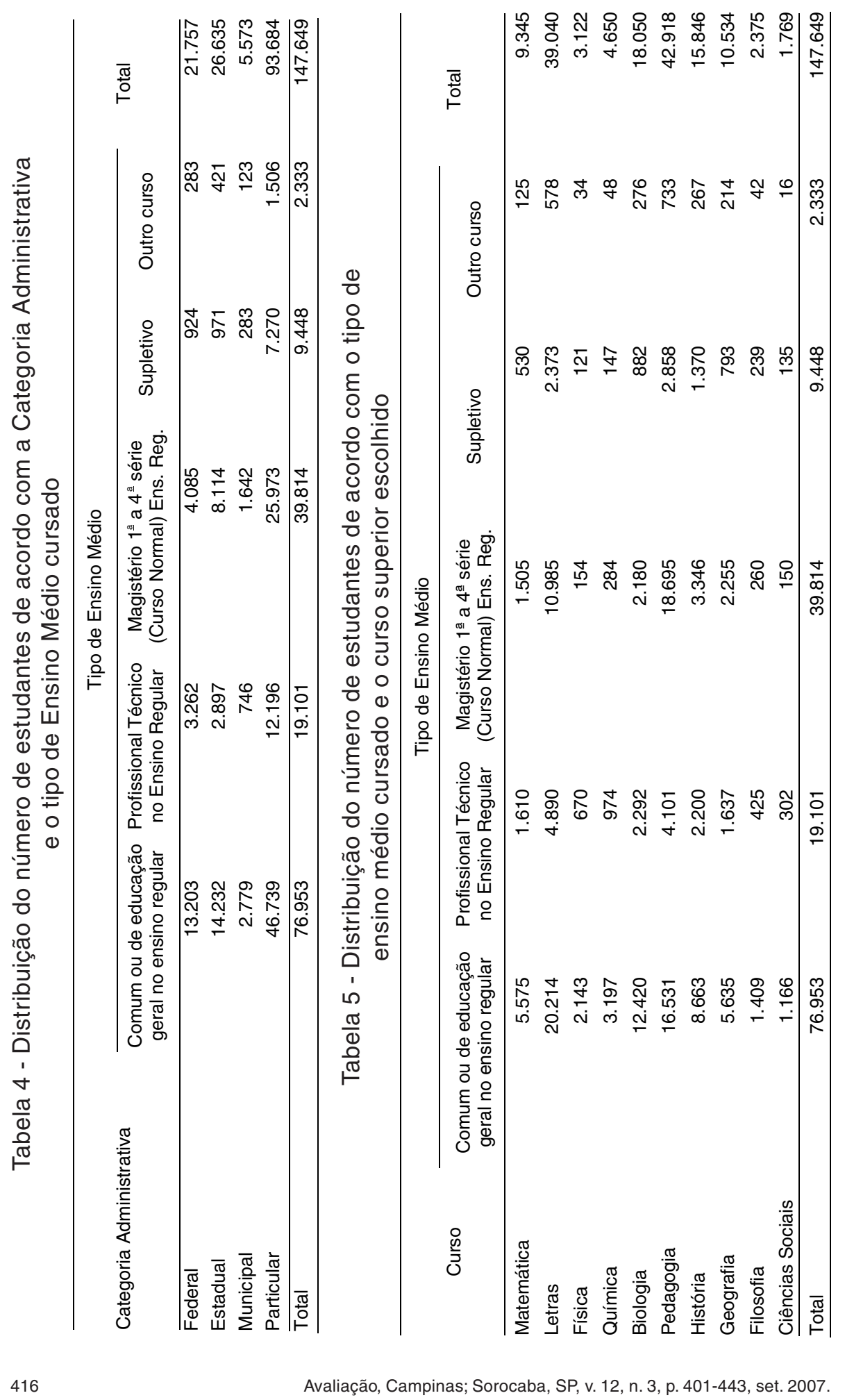


so profissionalizante de Magistério de $1^{\underline{a}}$ a $4^{\underline{a}}$ série (Curso Normal), no ensino regular; $12,9 \%$ concluíram o curso médio profissionalizante técnico (Eletrônica, Contabilidade, Agrícola) no ensino regular e apenas 6,4\% fizeram curso Supletivo (1,8\% deixou esta questão em branco ou duplicada).

Foi verificado também que os estudantes oriundos do Ensino Médio comum ou de Educação geral no Ensino regular, 60\% ( $N=46.119)$ ingressaram em Universidades, enquanto 18,8\% ( $N=14.439)$ ingressaram em Faculdades, Escolas e Institutos Superiores. Essa distribuição se mantém semelhante para os outros tipos de ensino médio. Existe diferença significativa de distribuição dos estudantes por organização acadêmica, quando são agrupados de acordo com o tipo de Ensino Médio cursado ( $\square^{2}$ [16] $=1744,604 ; p<0,001)$.

É possível verificar que a maior parte dos estudantes oriundos do Ensino Médio comum ou de educação geral no ensino regular ingressou em universidades e instituições particulares de ensino $(N=46.739)$. Foi verificada a existência de diferenças significativas quando os estudantes são agrupados de acordo com a categoria administrativa e o tipo de ensino médio cursado $\left(\square^{2}[12]=2049,114 ; p<0,001\right)$.

Ao analisar a distribuição de respondentes que cursaram Magistério no Ensino Médio, é possível verificar que grande parte optou por cursar Pedagogia $(48,2 \%)$ e Letras $(27,6 \%)$ no Ensino Superior (Tabela 5). É importante salientar que essa distribuição mostra-se semelhante para os outros tipos de ensino médio e confirma os dados do Censo 2004, que mostra que esses cursos absorvem a maioria dos ingressantes e também têm o maior número de concluintes no ensino superior (Tabelas 3 e 5). Verifica-se também a existência de diferença significativa de distribuição dos estudantes por carreira, quando são agrupados de acordo com o tipo de ensino médio cursado $\left(\square^{2}[36]=12986,259 ; p<0,001\right)$.

Além de se conhecer a formação dos Licenciandos, é importante também conhecer suas características principais, a situação sócio-econômica e cultural e outros aspectos relevantes do futuro professor. O quadro 1 resume algumas características, informadas em termos das porcentagens válidas. O total de estudantes de Licenciaturas que responderam pelo menos uma questão do componente de formação geral foi 184.460. Em cada uma das 105 questões do questionário sócio-econômico aparece uma abstenção entre 19 a $20 \%$. 
Quadro 1: Características predominantes dos estudantes das Licenciaturas (ENADE2005)

\begin{tabular}{|c|c|}
\hline Característica Predominante & $\%$ \\
\hline **Solteiro. & 63,7 \\
\hline **Branco. & 60,8 \\
\hline **Têm três ou mais irmãos. & 69,4 \\
\hline${ }^{\star *}$ Moram com os pais e/ou parentes ou esposa e filhos & 90,9 \\
\hline Moram com 3 a 6 membros da família & 51,5 \\
\hline Famílias que ganham até 3 salários mínimos. & 39,8 \\
\hline Trabalham 40 horas semanais & 43,6 \\
\hline Não recebe nenhum auxílio (bolsa de estudos ou financiamento para estudar). & 65,2 \\
\hline Tem pai com escolaridade mínima de ensino fundamental ( $8^{\mathrm{a}}$ série). & 59,2 \\
\hline Tem mãe com escolaridade mínima de ensino fundamental ( $8^{a}$ série). & 56,0 \\
\hline Tem conhecimento praticamente nulo de inglês. & 46,4 \\
\hline Tem conhecimento praticamente nulo de espanhol. & 42,8 \\
\hline Estuda, além das aulas, no mínimo uma hora e no máximo cinco horas semanais. & 73,1 \\
\hline ** Lê de 2 a 5 livros ao ano, excetuando-se os livros escolares. & 28,0 \\
\hline *Lê jomais apenas ocasionalmente. & 72,1 \\
\hline Utiliza a TV para se manter atualizado sobre os acontecimentos do mundo contemporâneo. & 58,4 \\
\hline Utiliza a biblioteca da instituição onde estuda com razoável freqüência ou muito freqüentemente. & 45,4 \\
\hline Tem, no acervo da biblioteca da Instituição, a sua principal fonte de pesquisa. & 50,5 \\
\hline Não desenvolve atividade acadêmica além das obrigatórias. & 45,0 \\
\hline Participa de eventos promovidos pela própria instituição (congressos, jornadas, seminários, etc.). & 67,9 \\
\hline Tem no cinema a sua principal atividade de lazer. & 42,6 \\
\hline Tem acesso à internet. & 82,9 \\
\hline Utiliza microcomputador para trabalhos escolares. & 94,9 \\
\hline **Utiliza correio eletrônico & 71,3 \\
\hline Afirma ter conhecimento de informática bom ou muito bom. & 79,2 \\
\hline *Considera a aquisição de formação profissional a principal contribuição do curso. & 61,1 \\
\hline
\end{tabular}

A partir das informações sumarizadas no quadro 1, é possível extrair algumas informações a respeito dos estudantes que cursam as Licenciaturas. Mais da metade deles são estudantes trabalhadores, matriculados em cursos noturnos, oriundos do ensino médio público, provenientes de famílias com mais de dois irmãos, com pais que completaram apenas o ensino fundamental (até $8^{a}$ série), matriculados em Universidades privadas, a maioria localizada na região sudeste. Trabalham de 20 a 40 horas, não 
recebem nenhum auxílio financeiro, as famílias (com uma média de cinco pessoas) vivem com até 10 salários. Tem conhecimento quase nulo de espanhol e inglês, lêem pouco e se informam dos acontecimentos pela televisão. Dedicam poucas horas semanais aos estudos e não desenvolvem atividades acadêmicas além das obrigatórias. Percebem-se como bons conhecedores de informática, usam correio eletrônico, têm acesso à internet e usam computador para fazer trabalhos escolares. Além disso, consideram que a aquisição de formação profissional é a principal contribuição que receberam ou estão recebendo do curso. 51,3\% dos estudantes de Licenciaturas consideraram que o nível de exigência do curso é adequado, enquanto $43,2 \%$ consideraram que o curso deveria ter exigido mais e apenas $0,8 \%$ considerou que poderia ter exigido menos.

Dos estudantes que afirmaram que lêem livros além dos livros escolares, 25,4\% escolhem obras literárias de ficção e $23 \%$ outros gêneros literários, mostrando diferença significativa de distribuição dos estudantes por hábito de leitura, quando são agrupados de acordo com o tipo de livros escolhidos para leitura $\left(\square^{2}[16]=2800,977 ; p<0,001\right)$.

Com relação às atividades de pesquisa, $40,5 \%$ dos estudantes de Licenciaturas afirmaram utilizar o acervo da biblioteca da própria instituição para esta atividade e 24,4 utilizam a Internet, sendo que $0,8 \%$ informaram que nunca realizaram atividades de pesquisa no curso. Foi observado também que $45,1 \%$ dos estudantes não desenvolveram nenhuma atividade acadêmica extracurso, enquanto que $54,9 \%$ desenvolveram algum tipo de atividade, seja monitoria, iniciação científica, trabalho em grupo de pesquisa ou outras atividades assemelhadas. As diferentes instituições deveriam investir e incentivar a participação em atividades extraclasse, pois isto é um diferencial para formação pessoal e profissional dos estudantes.

Quando perguntados a respeito do envolvimento em atividades de pesquisa de qualquer natureza, em pesquisas independentes ou supervisionadas, com professores ou com estudantes de pós-graduação, foi encontrado nas respostas que 54,9\% dos estudantes não tiveram interesse ou oportunidade de participar de pesquisas, enquanto $45,1 \%$ informaram participar desse tipo de atividade. Quando os estudantes são separados em ingressantes e concluintes, observa-se que $36,3 \%$ dos ingressantes e 53,7\% dos concluintes desenvolvem ou já haviam desenvolvido algum tipo de pesquisa, embora não se saiba a qual tipo de pesquisa os estudantes se referem, pois eles podem estar fazendo referência à pesquisa bibliográfica. O teste Qui-quadrado de Pearson $\left(\square^{2}[4]=4908,301 ; p<0,001\right)$ apontou diferenças significativas entre os grupos de ingressantes e concluintes. 


\section{Principais percepções dos estudantes de Licenciaturas sobre a IES, o curso e os professores.}

É de fundamental importância analisar a percepção que tanto os estudantes ingressantes quanto os concluintes possuem a respeito do trabalho desenvolvido pelos docentes do curso, bem como a avaliação feita sobre as disciplinas que compõem a grade curricular. Assim, foi solicitado ao estudante que indicasse se ele consegue perceber a existência de articulação entre a concepção do curso no qual está matriculado e o conhecimento da área, isto é, teorias, procedimentos, técnicas, instrumentos e outros com aspectos sociais, políticos e culturais da realidade e também com situações cotidianas e temas mais gerais.

Embora o componente de formação geral da prova não tenha questões diretamente vinculadas às disciplinas, é esperado, hoje em dia, em todos os níveis de ensino, que os docentes trabalhem, juntamente com os diferentes conteúdos, aspectos relacionados às questões sociais, políticas e culturais do mundo atual, com especial ênfase no impacto dessas questões para as IES. Duas questões do questionário sócio-econômico permitem visualizar como isso vem sendo desenvolvido.

Quando solicitados a avaliar as atividades dos docentes do curso com o currículo, $64,2 \%$ dos estudantes responderam que a concepção do curso articula o conhecimento da área (teorias, procedimentos, técnicas, instrumentos) com os aspectos sociais, políticos e culturais da realidade brasileira, mas, destes, apenas $26,7 \%$ responderam que isso ocorre sempre e $37,5 \%$ disseram que isto ocorre no ensino de novas disciplinas; além destes, $29,8 \%$ responderam que sim, mas apenas no ensino de algumas disciplinas.

Ainda buscando mais informações sobre o trabalho dos docentes e o currículo do curso de graduação no qual estão matriculados, aos estudantes foi perguntado se a concepção de curso e o trabalho dos professores nas várias disciplinas da grade curricular articulam o conhecimento da área (teorias, procedimentos, técnicas, instrumentos) com os temas gerais e situações do cotidiano. 95,1\% dos estudantes responderam afirmativamente, mas, as respostas se distribuem entre aqueles em que a articulação está presente em todas as atividades do curso $(27,6 \%)$, apenas no ensino de algumas disciplinas $(28,7 \%)$ e apenas no ensino de novas disciplinas $(38,8 \%)$.

$\mathrm{O}$ quadro 2 resume as alternativas escolhidas com maior freqüência, pelos estudantes, quando perguntados sobre as práticas dos professores do curso. 
Quadro 2. Respostas mais frequentes na avaliação, pelos licenciandos, da prática docente.

\begin{tabular}{|l|c|}
\hline Alternativa (s) com maior incidência de respostas & $\%$ \\
\hline $\begin{array}{l}\text { Todos ou quase todos os planos de ensino contêm objetivos, procedimentos de ensino e avaliação, } \\
\text { programa e bibliografia. }\end{array}$ & 86,2 \\
\hline Todos ou a maior parte dos professores discutem o plano de ensino ao início de cada disciplina. & 78,6 \\
\hline $\begin{array}{l}\text { As orientações do plano de ensino são relevantes ou altamente relevantes para os estudantes no } \\
\text { desenvolvimento do curso. }\end{array}$ & 79,0 \\
\hline Os professores (todos ou a maior parte deles) têm domínio atualizado do conteúdo que ministram. & 87,1 \\
\hline A maioria das aulas é expositiva com ou sem a participação dos estudantes. & 56,9 \\
\hline A maioria dos professores usa apostilas, cópias de trechos ou resumos de livros. & 67,0 \\
\hline A maioria ou todos os professores tem disponibilidade para orientação extraclasse. & 53,2 \\
\hline Os procedimentos do curso são adequados ou bastante adequados aos objetivos. & 64,5 \\
\hline $\begin{array}{l}\text { Os professores, em todas ou na maior parte das disciplinas, solicitam a realização de atividades de } \\
\text { pesquisa como estratégia de aprendizagem. }\end{array}$ & 42,7 \\
\hline Os professores usam recursos audiovisuais de forma ampla e adequada. & 41,8 \\
\hline $\begin{array}{l}\text { Os professores usam a tecnologia educacional com base na informática de forma restrita mas } \\
\text { adequada. }\end{array}$ & 38,5 \\
\hline O nível de exigência do curso é/foi na medida certa. & 51,3 \\
\hline $\begin{array}{l}\text { Provas escritas com questões discursivas são os instrumentos de avaliação mais usados pela maioria } \\
\text { dos professores }\end{array}$ & 60,1 \\
\hline
\end{tabular}

Quando analisam as práticas docentes, os estudantes de Licenciaturas consideram que os professores (ou a maioria deles) dominam o conteúdo relativo à disciplina que ministram e são atualizados nos conteúdos, mostrando disponibilidade para atendimento fora das aulas. Fazem uma apreciação altamente positiva a respeito dos planos de ensino, afirmando que todos ou a maior parte dos professores apresentam e discutem planos de ensino com orientações relevantes ou altamente relevantes para a compreensão e acompanhamento do curso, sendo planos bastante completos com objetivos, procedimentos de ensino e avaliação, programa e bibliografia. Mais da metade dos estudantes que responderam a esta questão consideraram que os procedimentos do curso são adequados ou bastante adequados aos objetivos apresentados e que a exigência do curso foi adequada.

Como pontos que precisam ser vistos com maior atenção, destacamse o método de ensino que, segundo a metade dos sujeitos é, basicamente, o de exposição oral sobre o conteúdo e isso muitas vezes é feito sem a participação dos estudantes; bem mais da metade afirmou que o material usado é bastante restrito (apostila e resumos de livros) e, como complemento, uma avaliação feita através de provas escritas, com questões discursivas. Como uma parte dos estudantes apontou que teve dificuldade nas questões discursivas e também porque não tinha aprendido os conteúdos solicitados na prova, é necessário que as IES e os cursos de formação 
de professores atentem para o progresso dos estudantes nos itens considerados essenciais naquela área e para como os estudantes estão sendo capazes de formular respostas para as diversas situações-problema apresentadas.

Um ponto central do Exame Nacional de Desempenho dos Estudantes é verificar se e de que maneira a IES está contribuindo para a formação do estudante, não apenas na parte referente à assimilação de conhecimentos sobre determinados objetos mas, particularmente, o que o estudante agrega na passagem por aquela instituição específica, com suas características peculiares e localizada em um determinado contexto, atendendo a um determinado tipo de população. Ao analisar a questão que se refere às diversidades e especificidades regionais, foi verificado que $37,7 \%$ dos estudantes responderam que as IES contribuíram amplamente para a reflexão desses aspectos, enquanto $35,7 \%$ afirmaram que contribuíram parcialmente. Considerando a amplitude e a diversidade cultural do Brasil, é necessário que essa temática seja mais bem trabalhada e discutida ao longo das disciplinas oferecidas.

Para que isso seja atingido, um primeiro aspecto deve estar presente e refere-se à integração das disciplinas, elemento avaliado no questionário sócio-econômico. Solicitados a avaliar o currículo do curso, 69.966 estudantes $(47,4 \%)$ de Licenciaturas afirmaram que o currículo é bem integrado, havendo clara vinculação entre as disciplinas, enquanto $57.498(38,9 \%)$ disseram ser relativamente integrado, já que as disciplinas se vinculam apenas por blocos ou áreas de conhecimento afins. Por outro lado, 9,9\% dos sujeitos afirmaram que o currículo não apresenta integração entre as disciplinas, ele é pouco integrado, já que poucas disciplinas estão articuladas; já 3,6\% afirmaram não saber responder a essa questão e as respostas de $0,2 \%$ dos sujeitos estavam duplicadas.

O professor tem uma tarefa primordial de questionar o mundo, levando seus estudantes a refletir sobre os temas mais importantes da sociedade em que vive. Através de algumas perguntas do questionário sócio-econômico, busca-se verificar como as IES estão desenvolvendo esses temas com seus estudantes. No presente artigo, é apresentado o expresso pelo conjunto dos estudantes de Licenciaturas que fizeram o ENADE 2005. Porém, cada um dos relatórios de curso de cada uma das instituições permite que se tenha uma idéia de como os estudantes daquele curso específico estão percebendo o trabalho que está sendo desenvolvido.

A tabela 6 sumariza as respostas mais freqüentes do conjunto de estudantes de Licenciaturas que responderam a estas questões.

Pela própria concepção do SINAES e da parte de formação geral do ENADE, é importante considerar se a Instituição de Educação Superior 
está contribuindo para a formação geral do estudante, isto é, se os cursos que formam os futuros professores propiciam e desenvolvem, ao longo das atividades de graduação, reflexões sobre a realidade social brasileira em função de temas como analfabetismo, diferentes tipos de discriminação, desigualdades econômicas e sociais, habitação, desemprego, dentre outros.

A partir das respostas a oito questões do questionário sócio-econômico foi verificado que analfabetismo e desigualdades econômicas e sociais são os temas mais desenvolvidos nas disciplinas, e habitação e segurança os menos desenvolvidos na percepção da maioria dos estudantes. Uma porcentagem próxima de $10 \%$ informou que não sabia responder a essas questões, possivelmente porque não foram levados ou motivados a refletir sobre esses temas. Isto necessitaria de um estudo mais aprofundado, porém, possivelmente são estudantes que estão em cursos de Licenciaturas mas não desejam ser professores, preocupando-se mais com as disciplinas de conteúdo específico.

Tabela 6: Contribuição da IES para a reflexão e práticas sociais

\begin{tabular}{|l|r|r|r|r|r|}
\hline \multicolumn{5}{|c|}{$\begin{array}{c}\text { Em que medida a sua Instituição contribui/contribuiu para que, } \\
\text { ao longo do seu curso de graduação, você reflita/refletisse } \\
\text { sobre a realidade social brasileira em função dos seguintes temas: }\end{array}$} \\
\hline & Amplamente & Parcialmente & Muito pouco & Nada & Não sei \\
\hline Analfabetismo & 46,2 & 32,3 & 12,4 & 4,1 & 4,9 \\
\hline $\begin{array}{l}\text { Desigualdades } \\
\text { econômicas e sociais. }\end{array}$ & 46,1 & 34,1 & 11,7 & 3,5 & 4,4 \\
\hline Desemprego & 35,9 & 36,4 & 16,1 & 5,7 & 5,7 \\
\hline Habitação & 26,8 & 34,4 & 20,2 & 10,3 & 8,2 \\
\hline $\begin{array}{l}\text { Discriminação racial, } \\
\text { gênero e minorias. }\end{array}$ & 43,4 & 30,8 & 13,4 & 5,8 & 6,5 \\
\hline $\begin{array}{l}\text { Diversidades e } \\
\text { especifidades } \\
\text { regionais }\end{array}$ & 37,7 & 35,7 & 14,4 & 4,7 & 7,4 \\
\hline $\begin{array}{l}\text { Segurança e } \\
\text { criminalidade }\end{array}$ & 29,5 & 36,4 & 19,0 & 8,1 & 6,8 \\
\hline $\begin{array}{l}\text { Exploração do trabalho } \\
\text { Infantil e/ou adulto }\end{array}$ & 32,5 & 31,7 & 18,3 & 9,6 & 7,7 \\
\hline
\end{tabular}

Se considerarmos apenas que houve contribuição (ampla ou parcial) para a reflexão, pode ser constatado que a maioria dos estudantes desta amostra apontou que houve sim contribuição, ao longo do curso, para o questionamento e reflexão sobre os temas referentes a desigualdades eco- 
nômicas e sociais $(80,2 \%)$; analfabetismo $(78,5 \%)$; discriminação racial, gênero e minorias $(74,2 \%)$; diversidades e especificidades regionais $(73,4 \%)$; desemprego $(72,3 \%)$; segurança e criminalidade $(65,9 \%)$; exploração do trabalho infantil e/ou adulto $(64,2 \%)$ e questões habitacionais $(61,2 \%)$.

Buscando verificar como as IES estão levando os estudantes a refletirem sobre as ações afirmativas e como isso é desenvolvido, o questionário sócio-econômico também perguntou aos estudantes (184.474 estudantes de Licenciaturas) se o curso que freqüentam ou estão concluindo oferece ou ofereceu oportunidades de atuação ativa em atividades comunitárias e se favorece a ampliação do conhecimento a respeito de ações comunitárias. Foi verificado que o conhecimento de ações comunitárias é trabalhado apenas em algumas disciplinas e que $33,1 \%$ do total de sujeitos afirmaram que a instituição onde estão não oferece uma atuação efetiva em programas comunitários.

Tabela 7: Percepção dos estudantes a respeito do envolvimento entre a IES e as ações comunitárias

\begin{tabular}{|l|r|r|r|r|r|}
\hline & $\begin{array}{c}\text { Programas } \\
\text { de extensão }\end{array}$ & $\begin{array}{c}\text { Várias } \\
\text { disciplinas }\end{array}$ & $\begin{array}{c}\text { Algumas } \\
\text { disciplinas }\end{array}$ & $\begin{array}{c}\text { Atividades } \\
\text { de pesquisa }\end{array}$ & $\begin{array}{c}\text { Não } \\
\text { oferece }\end{array}$ \\
\hline $\begin{array}{l}\text { Conhecimento de ações } \\
\text { comunitárias }\end{array}$ & 13,8 & 16,5 & $\mathbf{3 3 , 6}$ & 10,2 & 25,7 \\
\hline $\begin{array}{l}\text { Atuação efetiva em } \\
\text { iniciativas e programas } \\
\text { comunitários }\end{array}$ & 13,6 & 12,9 & 29,8 & 10,4 & $\mathbf{3 3 , 1}$ \\
\hline
\end{tabular}

Considerando que o envolvimento da escola e da família é importante para o bom desempenho dos estudantes e para uma gestão efetiva, os cursos que formam os futuros professores precisariam não apenas desenvolver conhecimentos a respeito das possíveis ações comunitárias mas, efetivamente, propiciar aos estudantes uma atuação eficaz através das ações de pesquisa e de extensão, o que é plenamente possível considerando que a maioria dos Licenciandos está matriculada em Universidades e a estas estão afeitas as atividades de ensino, pesquisa e extensão.

Resumindo, a oportunidade que a IES proporciona para a vivência e o conhecimento de ações comunitárias é expressa por 33,6\% dos estudantes quando afirmaram que o curso proporciona essa vivência apenas em algumas disciplinas, embora $25,7 \%$ dos estudantes tenham afirmado que o curso não oferece oportunidades. Foi observado também que 29,8\% dos estu- 
dantes afirmaram a existência de oportunidades de vivência e atuação em iniciativas e programas comunitários. Em oposição, foi verificado que $33,2 \%$ dos estudantes afirmaram que não houve oferta de oportunidades para vivência e atuação em iniciativas e programas comunitários. Seria necessário um refinamento deste estudo para serem evidenciadas as IES que não propiciam nenhuma oportunidade prática de atividades comunitárias. Esses dados sugerem a necessidade de maior ênfase das IES nesta área, devido à importância de se formar profissionais conscientes e que se preocupam e se engajam em iniciativas sociais e comunitárias.

De acordo com Brito (2002), a formação, na graduação, daqueles que se tornarão professores do ensino fundamental e médio deve

proporcionar aos estudantes um forte e amplo conjunto de experiências práticas de ensino que sejam efetivamente concebidas como atividades programática e intencionalmente organizadas, de tal forma que conservem uma estreita relação com a formação docente. Assim, a capacitação técnica, científica e política; o incentivo profissional, o fortalecimento do desejo de participação consciente no processo educativo mediante as atividades do magistério aparecem como aspectos essenciais da formação do professor.

Dentro desta idéia, a formação docente deve estar voltada não apenas ao conhecimento a respeito do conteúdo da área ou aos métodos mais eficazes de ensino mas também à formação de "bons pensadores", isto é, sujeitos capazes de transformar o aprendido nas várias disciplinas em ações transformadoras. Isso se dá não apenas na passagem pelas diferentes disciplinas e atividades componentes das atividades curriculares, mas pela efetiva participação em atividades programadas com a clara intenção de desenvolver competências e atitudes relevantes para a futura atuação docente.

Buscando verificar quais atividades de formação complementar são oferecidas aos estudantes além das atividades teóricas e práticas e como estes estão aproveitando e adequando estas atividades à integralização curricular, foram analisadas as frequiências de respostas nas questões sobre iniciação científica, extensão e monitoria, sendo, em seguida, analisada a amplitude da contribuição de tais programas.

Com relação à iniciação científica (IC), 45,2\% dos estudantes afirmaram nunca ter participado destas atividades e $43,8 \%$ dos estudantes responderam afirmativamente que as IES oferecem este tipo de atividade com aproveitamento regulamentar de conhecimentos para a integralização curricular, isto é, são usados como atividades componentes da formação 
profissional; por outro lado, $11,2 \%$ dos estudantes afirmaram que essa atividade não é oferecida e 41.191 licenciandos afirmaram que não sabiam informar sobre isso.

Poder-se-ia supor que essas respostas de desconhecimento tenham sido comuns aos ingressantes, pois ainda estavam no início do curso, mas as tabelas cruzadas mostraram uma frequiência bem próxima de ingressantes e concluintes que desconhecem tais programas.

Com relação à oferta de atividades de extensão além das atividades teóricas e práticas, $41,5 \%$ dos estudantes de Licenciaturas informaram que isso é feito na IES à qual ele pertence e também é aproveitada para a integralização curricular. Com relação à oferta desta atividade, $17,9 \%$ afirmaram que a mesma foi ampla; já 20,2\% apontaram que foi parcial e 45,2\% que não participaram desse tipo de programa.

Quando perguntados sobre a oferta e abrangência dos programas de monitoria, $41,8 \%$ dos licenciandos responderam de forma afirmativa e que oferecem este tipo de atividade com aproveitamento regular de conhecimentos para a integralização curricular; por outro lado $29,6 \%$ não souberam informar e $12,9 \%$ disseram que a IES não oferece esse tipo de atividade. Quando perguntados sobre os procedimentos para avaliação das atividades de iniciação científica, extensão e monitoria, aproximadamente $43 \%$ dos estudantes afirmaram que não houve qualquer tipo de avaliação e isso foi recorrente nos três casos. Dada a importância de envolver os estudantes em atividades efetivas de experiência, seria necessário que as diferentes IES avaliassem de forma sistemática e programada o impacto que estas atividades estão tendo nos estudantes.

Buscando verificar a percepção dos estudantes a respeito das maiores contribuições do curso para a formação, foi observado que $54,2 \%$ dos estudantes consideram a aquisição da formação profissional a principal contribuição do curso e $25,7 \%$ apontam a aquisição da cultura geral. Deve ser notado que $20,1 \%$ dos estudantes não souberam responder a esta questão; $8,4 \%$ se referiram à obtenção de diploma de nível superior; 5,6\% à aquisição de formação teórica e 2,0\% apontaram a possibilidade de melhores perspectivas de ganho profissional.

Quando os sujeitos são divididos em ingressantes e concluintes, observa-se que 38.133 ingressantes $(57,1 \%)$ e 41.710 dos concluintes $(51,4 \%)$ afirmaram que a aquisição de formação profissional é a principal contribuição do curso. Existe diferença significativa de distribuição dos estudantes segundo a opinião sobre a principal contribuição do curso quando são agrupados de acordo com a situação no curso $\left(\square^{2}[4]=983,748\right.$; $p<0,001)$. 
Os sujeitos foram perguntados a respeito da contribuição do curso para a assimilação crítica e foi observado que $42,2 \%$ consideraram que o curso contribui e/ou contribui parcialmente para a assimilação crítica enquanto $30,4 \%$ apontaram que contribuiu amplamente e somente $8,3 \%$ dos estudantes afirmaram que o curso não contribuiu ou desenvolveu tal competência.

\section{Contribuições do curso para o desenvolvimento de competências}

Tendo em vista que as Diretrizes Curriculares Nacionais estão voltadas para o desenvolvimento de habilidades e a formação de competências, buscou-se investigar a percepção dos futuros professores sobre em que medida o conjunto de disciplinas do curso estaria contribuindo para o desenvolvimento de algumas competências.

Com relação ao desenvolvimento de competências, pode ser observado que a maioria dos estudantes considera que houve o desenvolvimento dessas competências de forma total ou parcial. As respostas dos estudantes ingressantes e concluintes mostraram que, de maneira total ou parcial, os cursos de formação de professores estão desenvolvendo competências, embora sejam necessárias pesquisas mais aprofundadas a este respeito, inclusive sobre a compreensão que os estudantes possuem dessas competências.

\begin{tabular}{|l|r|}
\hline \multicolumn{1}{|c|}{ Competências } & $\begin{array}{c}\% \\
\text { (contribui) }\end{array}$ \\
\hline $\begin{array}{l}\text { Atuar de forma ética, com responsabilidade social para construção de uma } \\
\text { sociedade includente e social. }\end{array}$ & 84,8 \\
\hline Organizar, expressar e comunicar o pensamento. & 89,7 \\
\hline Raciocínar de forma lógica e fazer análise crítica. & 91,1 \\
\hline $\begin{array}{l}\text { Compreender processos, tomar decisão e solucionar de problemas no } \\
\text { âmbito da área de atuação. }\end{array}$ & 87,9 \\
\hline Atuar em equipes multi, pluri e interdisciplinares. & 75,7 \\
\hline Atuar como profissional responsável em relação ao meio ambiente. & 72,7 \\
\hline Observar, interpretar e análisar dados e informações. & 87,4 \\
\hline $\begin{array}{l}\text { Utilizar procedimentos de metodologia científica e de conhecimentos } \\
\text { tecnológicos na prática profissional. }\end{array}$ & 79,8 \\
\hline Utilizar os recursos de informática necessários ao exercício profissional. & 57,5 \\
\hline Assimilar criticamente os novos conceitos científicos e as novas tecnologias. & 72,53 \\
\hline
\end{tabular}


De modo geral, cerca de $80 \%$ dos futuros professores informaram que o curso que frequentam ou freqüentaram contribuiu para desenvolver as competências previstas nas Diretrizes Curriculares estabelecidas pelo Conselho Nacional de Educação (CNE). Isso permite afirmar que, na perspectiva dos estudantes, os cursos que frequentam têm contribuído para levá-los a uma atuação ética, com responsabilidade social para construção de uma sociedade includente e justa, permitindo a eles organizar, expressar e comunicar o pensamento, raciocinar de forma lógica e fazer análise crítica, compreender processos, tomar decisão e solucionar problemas no âmbito da área de atuação, atuar como profissional responsável em relação ao meio ambiente. Além disso permite observar, interpretar e analisar dados e informações, bem como utilizar procedimentos de metodologia científica e de conhecimentos tecnológicos na prática profissional, assimilando criticamente os novos conceitos científicos e as novas tecnologias. Apenas a competência na utilização de recursos de informática necessários ao exercício profissional foi apontada por uma parcela menor de estudantes e seria adequado que as IES tratassem especificamente deste item pois os recursos muitas vezes não são usados em toda a potencialidade.

\section{As Licenciaturas e a opção profissional}

Os cursos de Licenciatura passaram por um período no qual ocorreu uma diminuição na procura conforme mostrado na figura 1 . Os dados do Censo da Educação Superior Brasileira mostram que, em alguns casos, o número de estudantes que concluem o curso é extremamente baixo, por exemplo, nos cursos de Licenciaturas em Física, Filosofia, Química e Matemática. Na segunda metade do século XX, a carreira de professor era uma carreira de prestígio e o curso normal fornecia um diploma que permitia o exercício do magistério nas quatro séries do Ensino Fundamental. $\mathrm{Na}$ última década isto foi alterado e surgiu a exigência de curso superior de Pedagogia ou diploma obtido na Escola Normal Superior para o magistério na Educação Fundamental, como ocorre para as Licenciaturas específicas que habilitam o professor para o magistério de quinta a oitava série e no Ensino Médio.

Considerando que o presente artigo trata apenas dos estudantes de Licenciaturas, é importante conhecer as razões pelas quais os estudantes buscaram esses cursos que são voltados para a formação de professores para o ensino fundamental e médio, tanto de escolas públicas quanto privadas. 
Em relação à perspectiva profissional futura, $8,9 \%$ dos estudantes ainda não se decidiram; $32,9 \%$ dos estudantes ingressantes e concluintes afirmaram que pretendem se dedicar à atividade acadêmica e, posteriormente, buscar curso de pós-graduação, enquanto $21,4 \%$ trabalham em outra área mas pretendem mudar de atividade e exercer funções docentes. Além disso, $19,6 \%$ declararam que já trabalham na área e pretendem continuar nela; $13,6 \%$ pretendem prestar concurso para atividade em empresa pública e $3,3 \%$ pretendem trabalhar em empresa privada, sendo que $0,4 \%$ dos estudantes não respondeu.

Pode ser verificado através da análise dos dados que tanto ingressantes quanto concluintes compartilham de opiniões semelhantes a respeito de suas perspectivas profissionais no que se refere a buscar trabalhar na própria área de graduação e, futuramente, dedicar-se à atividade acadêmica e buscar curso de pós-graduação. Porém, observa-se a existência de diferença significativa de distribuição dos estudantes, segundo a opinião sobre a perspectiva profissional futura, quando são agrupados de acordo com a situação do curso $\left(\square^{2}[5]=4160,110 ; p<0,001\right)$.

Quando é analisada a opção pelo magistério, verifica-se que a maior parte dos estudantes expressa vontade de ser professor (73\%), sendo que somente $9,6 \%$ dos estudantes relatam que não querem tornar-se professores. Esses resultados podem ser mais bem visualizados na Figura 3.

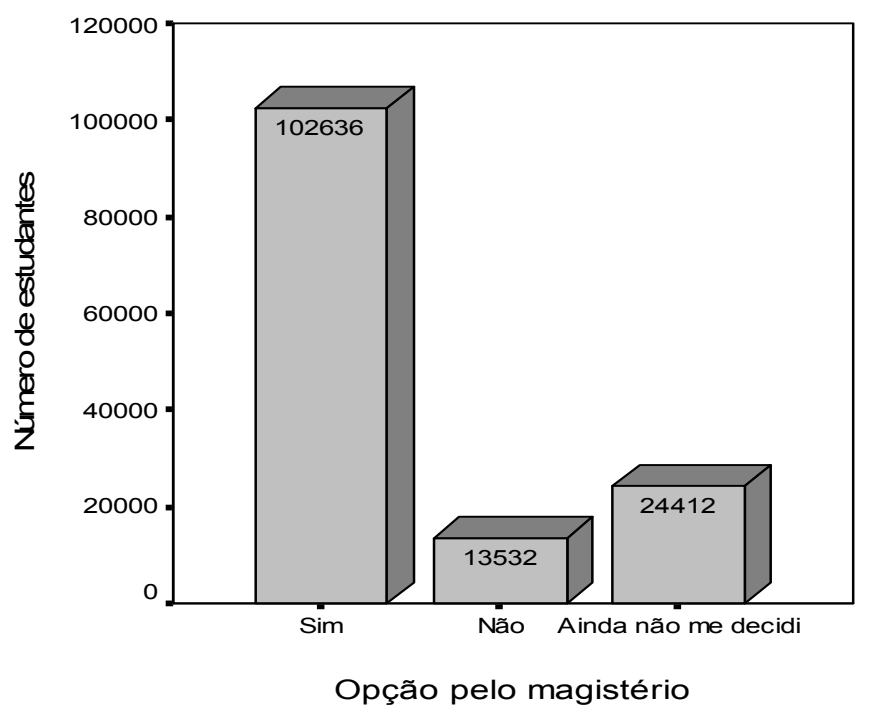

Figura 3 - Distribuição do número de estudantes de acordo com a opção pelo magistério 
Quando os estudantes são divididos em ingressantes e concluintes, verifica-se que $76,3 \%$ dos concluintes expressam vontade de seguir a carreira de magistério e, de forma semelhante $69,6 \%$ dos ingressantes também manifestaram a mesma opção profissional. Verifica-se que existe diferença significativa na distribuição dos estudantes segundo a opinião sobre a opção pelo magistério, quando são agrupados de acordo com a situação do curso $\left(\square^{2}[2]=920,474 ; p<0,001\right)$.

Quando é analisada a experiência anterior no magistério, pode ser verificado que $51,1 \%$ já tiveram experiência em docência, conforme a figura 4. Também deve ser notado que do total de estudantes que já tiveram experiência no magistério, 66,6\% são concluintes. Existe diferença significativa de distribuição dos estudantes segundo a experiência anterior no magistério, quando são agrupados de acordo com a situação do curso $\left(\square^{2}[1]=13880,098 ; p<0,001\right)$.

Dos estudantes que já tiveram experiência no magistério, constatouse que $59,1 \%$ já atuaram como professores do ensino regular em escola pública e 19,6\% como professores do ensino regular em escola privada. Esta distribuição dos dados deve ser estudada com cuidado, visto que os alunos que não tiveram experiência anterior não deveriam ter respondido a esta questão, conforme instrução dada. De forma geral, constata-se diferença significativa de distribuição dos estudantes segundo o local de atuação como professor, quando são agrupados de acordo com a situação do curso $\left(\square^{2}[5]=2125,400 ; p<0,001\right)$.

A Tabela 8 mostra a distribuição de estudantes de acordo com a principal razão de escolha pelo curso de graduação - Licenciatura e, pode-se verificar que mais da metade deles justificou a escolha porque querem ser professores $(54,8 \%)$. Um dado relevante e que deve ser estudado mais profundamente se refere à influência do papel do professor para a escolha profissional dos estudantes, visto que, para a amostra estudada, $11,5 \%$ justificaram a escolha afirmando que foram influenciados por um professor que foi um bom modelo exemplar. Existem vários estudos que mostram a influência dos professores na escolha profissional dos estudantes, mas não existe concordância, na literatura, sobre a influência dos professores nas atitudes e escolha profissional dos futuros professores.

$\mathrm{O}$ resultado relativo à quantidade de estudantes que escolhem o magistério para ter outra opção se não conseguirem exercer outra atividade, quando comparados com os resultados obtidos, na década de oitenta, em um estudo longitudinal desenvolvido junto aos estudantes dos cursos de Licenciaturas de uma universidade pública (Brito, 1992) mostrou que houve 
uma diminuição no número de estudantes que assinalam esta alternativa. Aparentemente, um maior número de estudantes está escolhendo ser professor como opção primeira e motivados pelo desejo de exercer o magistério. Entretanto, é necessária uma certa dose de cautela na interpretação destes dados porque a inclusão do curso de Pedagogia com as Licenciaturas específicas pode mostrar resultados não condizentes, isto é, a Pedagogia é caracterizada pelo magistério, enquanto as Licenciaturas específicas oferecem um número maior de opções. Além disso, seria necessário analisar a categoria administrativa e o curso. Estudos realizados ao longo das décadas de oitenta e noventa apresentados nas várias edições do Congresso Estadual Paulista sobre Formação de Professores realizados pela UNESP apontaram diferenças entre IES e cursos. De qualquer forma é importante assinalar que metade dos sujeitos participantes do ENADE 2005 afirmou que eles escolheram a Licenciatura porque querem ser professores.

Assim, foi verificado que $56,8 \%$ dos concluintes e $52,8 \%$ dos ingressantes afirmaram ter escolhido um curso de Licenciatura porque querem ser professores. Existe diferença significativa de distribuição dos estudantes segundo a razão de escolha pela Licenciatura quando são agrupados de acordo com a situação do curso $\left(\square^{2}[5]=595,566 ; p<0,001\right)$.

Tabela 8 - Distribuição do número de estudantes de acordo com a razão de escolha da Licenciatura.

\begin{tabular}{|c|c|c|c|c|}
\hline \multirow{2}{*}{$\begin{array}{l}\text { Razão de escolha pela } \\
\text { licenciatura }\end{array}$} & \multirow{2}{*}{$\begin{array}{l}\text { Número de } \\
\text { estudantes }\end{array}$} & \multicolumn{2}{|c|}{ Situação no Curso } & \multirow[t]{2}{*}{ Total } \\
\hline & & Concluinte & Ingressante & \\
\hline \multirow{2}{*}{ Porque quero ser professor } & № & 40.268 & 35.923 & 76.191 \\
\hline & $\%$ & 56,8 & 52,8 & 54,8 \\
\hline \multirow{2}{*}{$\begin{array}{l}\text { Para ter outra opção se não } \\
\text { conseguir exercer outra } \\
\text { atividade }\end{array}$} & № & 13.854 & 14.889 & 28.743 \\
\hline & $\%$ & 19,5 & 21,9 & 20,7 \\
\hline \multirow{2}{*}{ Por influência da família } & № & 3.240 & 2.360 & 5.600 \\
\hline & $\%$ & 4,6 & 3,5 & 4,0 \\
\hline \multirow{2}{*}{$\begin{array}{l}\text { Porque tive um bom professor } \\
\text { que me serviu de modelo }\end{array}$} & № & 7.726 & 8.210 & 15.936 \\
\hline & $\%$ & 10,9 & 12,1 & 11,5 \\
\hline \multirow{2}{*}{ Eu não quero ser professor } & № & 3.050 & 4.238 & 7.288 \\
\hline & $\%$ & 4,3 & 6,2 & 5,2 \\
\hline \multirow{2}{*}{$\begin{array}{l}\text { É o único curso próximo da } \\
\text { minha residência }\end{array}$} & № & 2.748 & 2.408 & 5.156 \\
\hline & $\%$ & 3,9 & 3,5 & 3,7 \\
\hline \multirow{2}{*}{ Total } & № & 70.886 & 68.028 & 138.914 \\
\hline & $\%$ & 100,0 & 100,0 & 100,0 \\
\hline
\end{tabular}


Em relação à opinião a respeito do quanto o curso oferece e/ou ofereceu um conjunto de competências que possam auxiliar a tarefa de professor, verifica-se que $62,3 \%$ dos estudantes consideraram que o curso possibilitou a aquisição de competências profissionais e apenas 7,1\% não apontaram como válidas as competências ensinadas para prática docente.

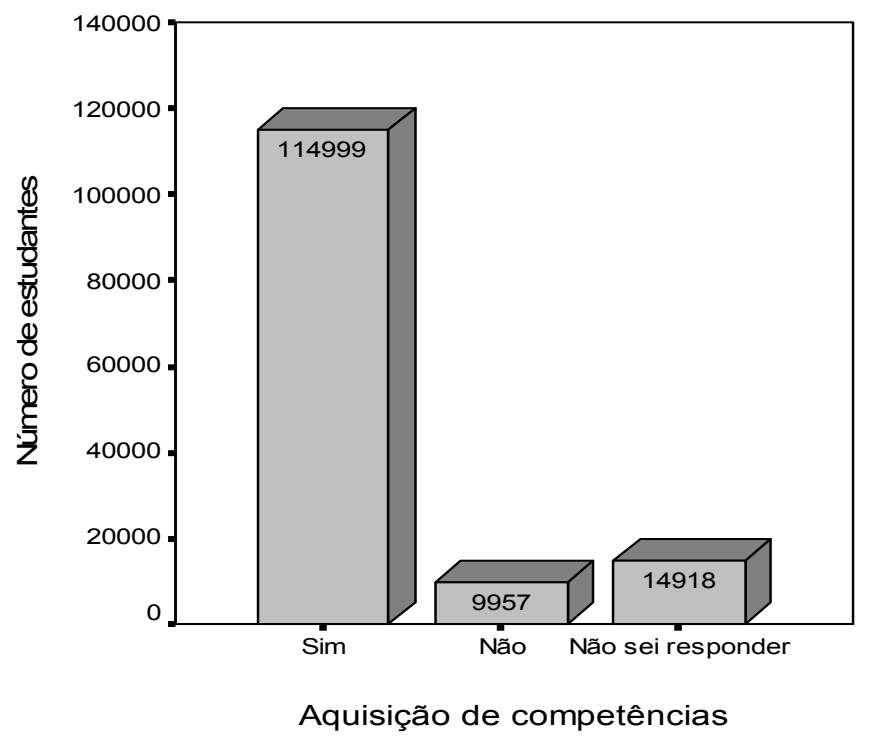

Figura 4 - Distribuição do número de estudantes de acordo com a perspectiva de aquisição de competências

Do total de 139.874 estudantes (68.670 ingressantes e 71.204 concluintes) que consideraram que o curso escolhido favorece e/ou favoreceu a aquisição de competências para a prática docente, $82,2 \%$ afirmaram que o curso teve contribuição para a aquisição de competências. Foi verificado que 60.778 concluintes $(43,5 \%)$ afirmaram que o curso contribuiu para a aquisição de competências necessárias ao desempenho profissional futuro e a mesma percepção tiveram 54.221 ingressantes $(38,8 \%)$. Por outro lado, 3.788 ingressantes $(2,7 \%)$ e 6.169 concluintes $(4,4 \%)$ afirmaram que o curso não contribuiu para a aquisição de competências. Além disso, 7,6\% dos ingressantes e 3,0\% dos concluintes afirmaram não saber responder a esta questão. Existe diferença significativa na distribuição dos estudantes segundo a perspectiva de aquisição de competências, quando são agrupados de acordo com a situação em que estão no curso, se ingressantes ou concluintes $\left(\square^{2}[2]=3647,631 ; p<0,001\right)$. 


\section{Desempenho dos estudantes de Licenciaturas no componente de Formação Geral do ENADE2005.}

As análises realizadas a seguir partem do pressuposto de que parte da variância do desempenho pode ser explicada por variáveis como, por exemplo, momento da formação em que os estudantes se encontram. Estudantes no final do curso (concluintes) devem, em média, apresentar melhor desempenho em relação aos estudantes que ainda estão iniciando o curso (ingressantes). Além disso, parte da variância do desempenho pode também estar relacionada aos cursos, isto é, os cursos podem diferir no que se refere ao efeito que têm em seus alunos. Por isso, alguns cursos podem concentrar alunos com maior desempenho e outros cursos alunos de pior desempenho. Por isso, as várias comparações realizadas devem ser analisadas com cautela já que, por exemplo, algumas regiões ou organizações acadêmicas podem ter diferentes concentrações de estudantes.

O componente de Formação Geral da prova do Exame Nacional de Desempenho dos Estudantes (ENADE) é composto por 10 (dez) questões elaboradas com a intenção de avaliar a capacidade do estudante para compreender textos e imagens, realizar comparações entre dados e informações, analisar e sintetizar as informações recebidas etc. Baseia-se, portanto, mais na verificação de habilidades acadêmicas gerais, contextualizadas em situações, fatos e temas da vida contemporânea, do que em competências profissionais específicas de alguma área de conhecimento (MEC, 2004a).

Antes de realizar as comparações de médias entre os grupos de variáveis, foi verificada a associação entre as diferentes partes da prova de Formação Geral. Observou-se que existe uma correlação positiva significativamente diferente de zero entre as notas dos estudantes na parte objetiva e na discursiva dessa prova $(r=0,299 ; p<0,001)$. Esses valores indicam que as notas nas duas partes da prova se apresentam moderadamente relacionadas, de maneira que tendem a aumentar no mesmo sentido, ou seja, quanto mais alta a nota do estudante na parte objetiva, maior é a tendência de aumento da nota também na parte discursiva. Porém, considera-se importante ressaltar os resultados apresentados na Tabela 12, em que 7,2\% dos respondentes deixaram em branco a parte discursiva da Formação Geral, enquanto que somente $0,4 \%$ não realizou a parte objetiva dessa prova. Além disso, é relevante considerar que, na avaliação feita ao final da prova, 40,1\% dos estudantes consideraram que a prova foi difícil devido à forma diferenciada de abordar os conteúdos e $25,1 \%$ consideraram difícil por desconhecimento do conteúdo solicitado nas questões. 
A Tabela 9 apresenta os resultados gerais de desempenho referentes à prova de Formação Geral, discriminados por área de conhecimento, trazendo, respectivamente, os resultados da média dos ingressantes, dos concluintes, a média de desempenho de todos os estudantes que realizaram a prova na área (sem distinção entre a situação de ingressante e concluinte) e o ganho médio no desempenho entre concluintes e ingressantes.

Foi verificado que em todas as áreas de licenciatura avaliadas no ENADE2005, os estudantes concluintes tiveram, em média, desempenho superior ao dos estudantes ingressantes. Em termos de resultados absolutos, verificou-se que a média geral de acertos ficou em 55,5 pontos e que a média dos ganhos em desempenhos médios foi de 1,9 pontos.

Comparando-se os resultados absolutos das diversas áreas, constatase que o melhor desempenho em Formação Geral foi da área de Geografia, seguido dos resultados de Física e Letras. O resultado mais baixo foi da área de Pedagogia e Química, cujos resultados apresentaram-se abaixo da média geral de acertos. Quanto ao ganho em desempenho médio entre os concluintes e os ingressantes, observam-se, de modo geral, resultados mais positivos nas áreas de Biologia, Filosofia e Química do que nas demais áreas. Os resultados da análise de variância (ANOVA) indicaram haver diferenças significativas de desempenho na Formação Geral por cursos (em que o curso de Geografia tendeu a apresentar desempenhos mais elevados) e entre ingressantes e concluintes (de forma que os concluintes tenderam a apresentar desempenhos mais elevados em todas as áreas).

Tabela 9 - Desempenho geral dos estudantes no componente de Formação Geral.

\begin{tabular}{lcccc}
\hline \multirow{2}{*}{ Área } & \multicolumn{4}{c}{ Formação Geral } \\
\cline { 2 - 5 } & Ingressante & Concluinte & Média & $\begin{array}{c}\text { Ganho em } \\
\text { desempenho médio }\end{array}$ \\
\hline Matemática & 54,366 & 56,255 & 55,252 & 1,889 \\
Letras & 57,430 & 58,748 & 58,094 & 1,318 \\
Física & 57,464 & 60,287 & $\mathbf{5 8 , 5 4 9}$ & 2,823 \\
Química & 52,331 & 55,735 & 53,947 & 3,404 \\
Biologia & 55,936 & 60,711 & 58,080 & 4,775 \\
Pedagogia & 49,230 & 51,190 & 50,279 & 1,960 \\
História & 56,117 & 57,859 & 56,966 & 1,742 \\
Geografia & 61,408 & 63,412 & $\mathbf{6 2 , 4 6 9}$ & 2,004 \\
Filosofia & 55,925 & 59,872 & 57,784 & 3,947 \\
Ciências & 52,943 & 55,391 & 54,349 & 2,448 \\
Sociais & 54,546 & 56,498 & 55,523 & 1,952 \\
\hline Total & & & & \\
\hline
\end{tabular}


Observa-se que, tanto na parte objetiva quanto na discursiva da Formação Geral, em todas as Licenciaturas avaliadas no ENADE2005, os estudantes concluintes tiveram, em média, desempenhos superiores ao dos estudantes ingressantes. Em termos de resultados absolutos, analisandose os resultados de todo o conjunto de estudantes de licenciatura, verificou-se que a média geral de acertos da parte objetiva foi de 67,2 pontos e a média da parte discursiva foi de 41,2 pontos. A média dos ganhos em desempenhos médios entre concluintes e ingressantes na parte objetiva foi de 2,5 pontos e na parte discursiva de 1,3 pontos.

Comparando-se os resultados absolutos das diversas áreas, constatase que o melhor desempenho nas questões objetivas, tanto entre concluintes quanto para ingressantes, foi na área de Física. Nas questões discursivas, verifica-se que o melhor desempenho, tanto entre concluintes quanto para ingressantes, foi da área de Geografia. A Pedagogia apresentou o resultado mais baixo, tanto para ingressantes quanto para concluintes, nas questões objetivas e discursivas, resultado este abaixo da média geral de acertos. Este resultado é preocupante quando se considera que a Pedagogia forma os professores que atuarão junto aos alunos no início da escolaridade e pressupõe uma formação geral e um domínio dos conteúdos da área bastante fortes, o que não está ocorrendo.

Tabela 10 - Estatísticas descritivas do desempenho no componente de Formação Geral por tipo de questão, área e situação do estudante no curso.

\begin{tabular}{|c|c|c|c|c|c|c|c|}
\hline \multirow{2}{*}{$\begin{array}{l}\text { Situação } \\
\text { do } \\
\text { Estudante }\end{array}$} & \multirow{2}{*}{ Área } & \multicolumn{3}{|c|}{ Questões objetivas } & \multicolumn{3}{|c|}{ Questões discursivas } \\
\hline & & Média & $\begin{array}{l}\text { Desvio } \\
\text { Padrão }\end{array}$ & $\mathrm{N}$ & Média & $\begin{array}{l}\text { Desvio } \\
\text { Padrão }\end{array}$ & $\mathrm{N}$ \\
\hline \multirow{11}{*}{ Concluinte } & Matemática & 67,426 & 20,9116 & 8.781 & 42,595 & 20,1939 & 8.778 \\
\hline & Letras & 69,654 & 19,6108 & 22.395 & 45,408 & 22,3606 & 22.395 \\
\hline & Física & 72,431 & 21,3793 & 1.377 & 45,435 & 25,9376 & 1.377 \\
\hline & Química & 69,619 & 20,5838 & 2.706 & 38,758 & 20,3671 & 2.706 \\
\hline & Biologia & 70,494 & 19,5744 & 9.240 & 48,746 & 20,5785 & 9.240 \\
\hline & Pedagogia & 65,892 & 20,2659 & 28.553 & 33,213 & 16,1826 & 28.553 \\
\hline & História & 70,459 & 20,1281 & 8.771 & 42,449 & 24,7693 & 8.771 \\
\hline & Geografia & 69,657 & 19,9447 & 6.406 & 55,771 & 23,9266 & 6.406 \\
\hline & Filosofia & 71,721 & 21,1596 & 2.133 & 45,293 & 20,8534 & 2.129 \\
\hline & $\begin{array}{l}\text { Ciências } \\
\text { Sociais }\end{array}$ & 66,556 & 30,1142 & 1.996 & 41,751 & 26,3253 & 1.995 \\
\hline & Total & 68,461 & 20,4768 & 92.358 & 41,866 & 21,7631 & 92.350 \\
\hline
\end{tabular}


Tabela 10 - Estatísticas descritivas do desempenho no componente de Formação Geral por tipo de questão, área e situação do estudante no curso. (continuação)

\begin{tabular}{|c|c|c|c|c|c|c|c|}
\hline \multirow{2}{*}{$\begin{array}{l}\text { Situação } \\
\text { do } \\
\text { Estudante }\end{array}$} & \multirow[b]{2}{*}{ Área } & \multicolumn{3}{|c|}{ Questões objetivas } & \multicolumn{3}{|c|}{ Questões discursivas } \\
\hline & & Média & $\begin{array}{l}\text { Desvio } \\
\text { Padrão }\end{array}$ & $\mathrm{N}$ & Média & $\begin{array}{l}\text { Desvio } \\
\text { Padrão }\end{array}$ & $\mathrm{N}$ \\
\hline \multirow{11}{*}{ Ingressante } & Matemática & 64,841 & 21,7430 & 9.927 & 41,548 & 19,9771 & 9.923 \\
\hline & Letras & 67,272 & 20,0393 & 22.068 & 45,391 & 21,9193 & 22.068 \\
\hline & Física & 69,445 & 20,9031 & 2.205 & 42,810 & 24,4628 & 2.205 \\
\hline & Química & 66,058 & 20,9638 & 2.992 & 35,545 & 20,1698 & 2.992 \\
\hline & Biologia & 66,056 & 20,4449 & 11.342 & 43,558 & 20,9153 & 11.342 \\
\hline & Pedagogia & 63,384 & 20,6949 & 24.804 & 31,922 & 16,2085 & 24.804 \\
\hline & História & 68,358 & 20,4619 & 9.212 & 41,147 & 23,7771 & 9.212 \\
\hline & Geografia & 68,039 & 19,9472 & 5.693 & 53,292 & 23,5730 & 5.693 \\
\hline & Filosofia & 67,833 & 22,6995 & 2.393 & 41,359 & 21,7485 & 2.391 \\
\hline & $\begin{array}{l}\text { Ciências } \\
\text { Sociais }\end{array}$ & 64,756 & 29,1579 & 1.480 & 38,503 & 26,3276 & 1.480 \\
\hline & Total & 65,956 & 20,8738 & 92.116 & 40,591 & 21,5054 & 92.110 \\
\hline
\end{tabular}

A Tabela 11 apresenta o desempenho de ingressantes e concluintes por região geográfica do país, em cada área de conhecimento. São destacados os principais resultados, porém deve ser considerado que, em algumas áreas, o número de cursos (e de estudantes) que prestaram o exame pode ser insuficiente para determinar uma análise mais significativa do ponto de vista regional. Além disso, em alguns casos, o número de participantes de uma região é relativamente maior que das outras, fato que deve ser considerado ao analisar a média geral das regiões do país.

Os dados da Tabela 11 apontam que os estudantes de Licenciatura das IES da região Sudeste tiveram desempenho superior aos das demais regiões na Formação geral, seguidos, na ordem, pelos estudantes das regiões Sul, Nordeste, Norte e Centro-Oeste. A diferença de desempenho entre as regiões, neste componente da prova, considerando as médias expostas, foi pequena, inferior a três (3) pontos. Os resultados da análise de variância (ANOVA) indicaram haver diferenças significativas de desempenho na Formação Geral entre as regiões participantes, de forma que os estudantes da região sudeste tenderam a apresentar desempenhos mais elevados. Observa-se, igualmente, que os estados da região sudeste têm desempenhos médios superiores em cinco das dez áreas avaliadas e os esta- 
dos da região sul obtiveram melhores desempenhos em duas; a área de Geografia que obteve o melhor desempenho na Formação Geral está incluida na região sudeste.

Tabela 11 - Média dos estudantes de Licenciaturas na parte de Formação Geral, por região geográfica.

\begin{tabular}{lcccccc}
\hline \multirow{2}{*}{ Área } & \multicolumn{5}{c}{ Região } & \multirow{2}{*}{ Total } \\
\cline { 2 - 6 } & Norte & Nordeste & Sudeste & Sul & Centro-Oeste & \\
\hline Matemática & $\mathbf{5 5 , 7 5 4}$ & 55,137 & 55,564 & 54,656 & 54,862 & 55,252 \\
\hline Letras & 55,845 & 56,405 & $\mathbf{5 9 , 3 8 3}$ & 58,842 & 55,935 & 58,094 \\
\hline Física & 56,516 & 59,875 & $\mathbf{6 1 , 2 3 0}$ & 54,948 & 53,090 & 58,549 \\
\hline Química & 54,539 & 54,060 & 53,097 & 54,680 & $\mathbf{5 6 , 1 6 4}$ & 53,947 \\
\hline Biologia & 58,771 & 56,661 & $\mathbf{5 9 , 2 9 4}$ & 57,109 & 57,147 & 58,080 \\
\hline Pedagogia & 49,876 & 50,409 & $\mathbf{5 0 , 9 7 5}$ & 50,288 & 47,736 & 50,279 \\
\hline História & $\mathbf{5 8 , 2 9 0}$ & 56,414 & 57,715 & 58,233 & 53,267 & 56,966 \\
\hline Geografia & 60,164 & 59,118 & $\mathbf{6 5 , 1 5 2}$ & 62,274 & 62,815 & 62,469 \\
\hline Filosofia & 57,040 & 55,541 & 58,794 & $\mathbf{5 8 , 8 7 5}$ & 55,861 & 57,784 \\
\hline Ciências Sociais & $\mathbf{6 1 , 5 9 1}$ & 57,902 & 53,010 & 48,222 & 57,145 & 54,349 \\
\hline Total & 54,448 & 55,175 & 56,350 & 55,388 & 53,671 & 55,523 \\
\hline
\end{tabular}

A Tabela 12 apresenta o desempenho dos estudantes na Formação Geral do exame, sem distinção entre ingressantes e concluintes. Os dados são apresentados separadamente para instituições públicas e privadas. No caso das instituições públicas, os dados foram categorizados para as IES federais, estaduais e municipais.

Os dados da Tabela 12 apontaram que os estudantes de Licenciatura das IES federais tiveram desempenho superior aos das demais categorias administrativas na Formação geral, seguidos, na ordem, pelos estudantes de IES estaduais, particulares e municipais. A diferença de desempenho entre as categorias, nesta parte da prova, considerando as médias expostas foi de, no máximo, 6 pontos. Os resultados da análise de variância (ANOVA) indicaram haver diferenças significativas de desempenho na Formação Geral entre as categorias participantes, de forma que os estudantes das IES federais tenderam a apresentar desempenhos mais elevados. Ao analisar os resultados por área, verifica-se que o desempenho dos estudantes das IES federais foi superior ao das demais em 9 das 10 áreas de Licenciatura estudadas, de forma que, nas IES municipais, somente a área de Filosofia obteve maior desempenho. 
Tabela 12 - Desempenho dos estudantes na Formação Geral por área e categoria administrativa da Instituição

\begin{tabular}{lccccc}
\hline \multirow{2}{*}{ Área } & \multicolumn{4}{c}{ Categoria Administrativa } & \multirow{2}{*}{ Total } \\
\cline { 2 - 5 } & Federal & Estadual & Municipal & Particular & \\
\hline Matemática & 57,921 & 56,408 & 53,329 & 54,348 & 55,252 \\
\hline Letras & 62,127 & 59,316 & 56,603 & 57,114 & 58,094 \\
\hline Física & 60,046 & 58,734 & 50,546 & 55,908 & 58,549 \\
\hline Química & 57,599 & 55,365 & 51,019 & 51,007 & 53,947 \\
\hline Biologia & 64,425 & 61,180 & 54,420 & 56,541 & 58,080 \\
\hline Pedagogia & 52,931 & 52,249 & 48,982 & 49,438 & 50,279 \\
\hline História & 62,377 & 56,164 & 52,179 & 56,169 & 56,966 \\
\hline Geografia & 66,486 & 62,142 & 54,724 & 61,619 & 62,469 \\
\hline Filosofia & 59,801 & 55,919 & 62,548 & 57,344 & 57,784 \\
\hline Ciências Sociais & 58,316 & 45,254 & 27,430 & 55,863 & 54,349 \\
\hline Total & 59,579 & 56,966 & 52,925 & 54,237 & 55,523 \\
\hline
\end{tabular}

Ao analisar o desempenho dos estudantes na parte de Formação Geral por área e organização acadêmica da Instituição, pode-se notar que os Centros de Educação Tecnológica apresentaram desempenhos médios superiores para as Licenciaturas em Física $(M=64,6)$; Biologia $(M=64,5)$; Química $(M=57,37)$; Matemática $(57,015)$ e Geografia $(M=73,587)$. Já os estudantes de Pedagogia dos Centros de Educação Tecnológica foram os que apresentaram os piores resultados $(\mathrm{M}=30,48)$. Os estudantes de Licenciatura em História, Filosofia, Pedagogia e Letras que obtiveram os melhores desempenhos são aqueles matriculados nas Universidades.

Tabela 13 - Desempenho dos estudantes na Formação Geral, por área e organização acadêmica da Instituição.

\begin{tabular}{lcccccc}
\hline \multirow{2}{*}{ Área } & \multicolumn{5}{c}{ Organização Acadêmica } & \\
\cline { 2 - 6 } & Universidade & $\begin{array}{c}\text { Centro } \\
\text { Universitário }\end{array}$ & $\begin{array}{c}\text { Faculdades } \\
\text { Integradas }\end{array}$ & $\begin{array}{c}\text { Fac. Escolas e } \\
\text { Instit. Superiores }\end{array}$ & $\begin{array}{c}\text { Centros Educ. } \\
\text { Tecnológica }\end{array}$ & Total \\
\hline Matemática & 55,890 & 54,390 & 54,153 & 55,034 & $\mathbf{5 7 , 0 1 5}$ & 55,252 \\
\hline Letras & 59,275 & 58,950 & 56,804 & 55,539 & - & 58,094 \\
\hline Física & 58,672 & 55,227 & 55,084 & 56,916 & 64,636 & 58,549 \\
\hline Química & 54,982 & 50,198 & 50,652 & 50,593 & $\mathbf{5 7 , 3 6 7}$ & 53,947 \\
\hline Biologia & 59,494 & 57,380 & 54,819 & 55,368 & 64,459 & 58,080 \\
\hline Pedagogia & 51,178 & 50,593 & 49,050 & 48,907 & 30,487 & 50,279 \\
\hline História & 57,889 & 56,765 & 55,743 & 54,616 & - & 56,966 \\
\hline Geografia & 63,893 & 63,576 & 61,312 & 57,676 & $\mathbf{7 3 , 5 8 7}$ & 62,469 \\
\hline Filosofia & 58,482 & 56,140 & 56,755 & 56,262 & - & 57,784 \\
\hline Ciênc. Sociais & 55,154 & 38,349 & 56,454 & 61,303 & - & 54,349 \\
\hline Total & 56,725 & 55,319 & 54,201 & 52,770 & 62,423 & 55,523 \\
\hline
\end{tabular}


As estatísticas referentes às análises de variância realizadas para a avaliação do desempenho na Formação Geral estão apresentadas na Tabela 14, além das devidas medidas de associação entre as variáveis testadas.

Tabela 14 - Análise de variância para testar diferenças de desempenho entre os estudantes na Formação Geral

\begin{tabular}{|c|c|c|c|c|c|c|}
\hline Fonte de variação & $\begin{array}{l}\text { Soma de } \\
\text { quadrados }\end{array}$ & $\begin{array}{l}\text { Graus de } \\
\text { liberdade }\end{array}$ & $\begin{array}{l}\text { Quadrado } \\
\text { Médio }\end{array}$ & $\begin{array}{c}\text { Estatística } \\
F\end{array}$ & $\begin{array}{c}\text { Significância } \\
\text { do teste }(p)\end{array}$ & $\begin{array}{c}\text { Coeficiente } \\
E_{t a}^{2}\end{array}$ \\
\hline Região & 147081,925 & 4 & 36770,481 & 126,701 & 0,000 & 0,003 \\
\hline $\begin{array}{l}\text { Categoria } \\
\text { Administrativa }\end{array}$ & 774423.125 & 3 & 258141,042 & 900,036 & 0,000 & 0,014 \\
\hline $\begin{array}{l}\text { Organização } \\
\text { Acadêmica }\end{array}$ & 501610.001 & 4 & 125402,500 & 434,984 & 0,000 & 0,009 \\
\hline Estudante X FG & 175670,068 & 1 & 175670,068 & 605,645 & 0,000 & 0,003 \\
\hline $\begin{array}{l}\text { Parte Objetiva FG } \\
\text { X Estudante X } \\
\text { Área }\end{array}$ & 289282,122 & 1 & 289282,122 & 676,687 & 0,000 & 0,004 \\
\hline $\begin{array}{l}\text { Parte discursiva } \\
\text { FG X Estudante X } \\
\text { Área }\end{array}$ & 74904,669 & 1 & 74904,669 & 160,031 & 0,000 & 0,001 \\
\hline Área X Estudante & 2593205,223 & 9 & 288133,914 & 1040,343 & 0,000 & 0,048 \\
\hline
\end{tabular}

Pode ser verificado que existem diferenças significativas quando são analisadas as diferenças de desempenho dos estudantes na parte de Formação Geral sendo consideradas como fontes de variação a região, a categoria administrativa, a organização acadêmica e as interações entre o momento do estudante no curso (ingressante ou concluinte), o tipo de questão (objetiva ou descritiva) e a área à qual pertence o estudante.

\section{Conclusão e discussão dos dados}

Os resultados obtidos através do questionário sócio-econômico e através das notas das provas do ENADE2005 permitem conhecer melhor os estudantes dos cursos de formação de professores e observar o comportamento desses cursos ao longo dos anos.

Alguns resultados são bastante preocupantes e, dentre estes, podemos destacar o baixo número de professores sendo formados nos cursos de Matemática, Física e Química e, além da questão do pequeno número de estudantes que concluem o curso deve ser destacado também o baixo desempenho dos estudantes na parte de Formação Geral da prova (por enquanto, única parte da prova que permite comparações por ser feita por todos os participantes). 
É importante lembra que a Formação Geral não é uma prova de conhecimentos gerais, mas sim uma verificação dos conhecimentos que o estudante agrega ao longo de sua trajetória na IES, não estando vinculado a nenhuma disciplina. Considerando que o desempenho refere-se a apenas um único exame, aplicado em larga escala, se formos analisar as médias verificamos que, de modo geral, estas foram muito baixas. Como a proposta do ENADE é de uma análise de mudança, espera-se que os estudantes que fizeram o exame como ingressantes progridam nos vários itens que compõem a prova, itens estes presentes nas diretrizes curriculares dos diferentes cursos e apresentem incremento significativo quando realizarem o exame como concluintes.

Um outro resultado que merece destaque refere-se ao fato de a maioria dos estudantes de licenciaturas estarem matriculados em IES privadas e em cursos noturnos. Seria interessante que as IES públicas dessem maior ênfase aos cursos de formação de professores ampliando o número de vagas e as maneiras de possibilitar aos estudantes a permanência no curso. Além disso, a área de Exatas deveria buscar maneiras de estimular os estudantes a buscar cursos destas áreas; talvez uma maneira de conseguir aumentar a busca por estes cursos seja desenvolvendo nos estudantes atitudes positivas em relação à Matemática.

É importante que os cursos de Licenciatura fortaleçam a articulação da teoria com a prática, valorizando a pesquisa individual e coletiva, assim como os estágios e a participação em atividades de extensão que devem ser promovidas pela Instituição de Ensino Superior. É fundamental que o futuro professor tenha um sólido conhecimento, não na forma de "estoque" armazenado, mas na forma de "domínio conceitual", que o torne capaz de ajudar seus alunos a serem também agentes de sua formação, aproveitando ao máximo a riqueza dos espaços de conhecimento propiciados pelas multimídias. Os futuros professores devem dominar conjuntos de competências que reflitam a estreita relação entre o desenvolvimento e a aprendizagem do indivíduo, a aquisição, a manutenção e o uso dos conhecimentos, adquiridos tanto dentro como fora do contexto escolar.

Em texto anterior (BRITO, 2002), foi enfatizada a necessidade de que os cursos de formação de professores propiciem práticas pedagógicas inseridas no contexto maior dos cursos, buscando trabalhar de forma mais próxima do conjunto de atividades que serão exercidas futuramente pelos professores. Tendo em vista as várias e rápidas mudanças pelas quais passa a sociedade e considerando que a formação de professores está inserida em um contexto que exige cada vez mais práticas de ensino que valorizem 
o pensamento crítico, a flexibilidade e a capacidade de questionar padrões sociais, os cursos de Licenciatura deveriam ter como objetivo principal formar bons pensadores.

Assim, os cursos de formação de professores, além de trabalhar os recursos metodológicos e o conjunto de conhecimentos da área deve também trabalhar os diferentes processos de pensamento, apoiados na crença de que levar os estudantes a desenvolver plenamente o potencial de pensamento é um dos objetivos mais importantes da educação. Ainda de acordo com o texto citado, é função das disciplinas pedagógicas promover o pensamento e o entendimento, estabelecer as relações entre os aspectos cognitivos e a didática, desenvolver atitudes positivas em relação à disciplina que irão ensinar e desenvolver também crenças de eficácia como professores, além de prover o professor em formação de competências que permitam a ele tornar-se um pesquisador em sala de aula.

A discussão de novos cenários e de um novo perfil de professor mostra que os currículos dos Cursos de Licenciatura devem ser elaborados tendo como objetivo desenvolver as habilidades acadêmicas e as competências profissionais. O desenvolvimento profissional do professor inclui, necessariamente, o desenvolvimento de competências profissionais atadas a um processo dinâmico de refletir sobre a ação que desenvolve na sala de aula, buscando modificar os pontos considerados críticos e uma constante transformação da ação educativa.

\section{REFERÊNCIAS}

ANDRADE, D. F.; TAVARES, H. R.; VALLE, R. C. Teoria da Resposta ao Item: conceitos e aplicações. São Paulo: Associação Brasileira de Estatística, 2000.

BARREYRO, G. B. Do Provão ao SINAES: o processo de construção de um novo modelo de avaliação da Educação Superior. Avaliação, Campinas, RAIES v. 09, n. 02, p. 37-49, 2004

BRITO, M.R.. F. Licenciaturas: dificuldades e tentativas de solução. CONFERÊNCIA BRASILEIRA DE EDUCAÇÃO, 3, 1984, São Paulo. Anais... São Paulo: Loyola, 1984.

BRITO, M. R. F. Acompanhamento e Avaliação dos Cursos de Licenciaturas da Faculdade de Educação da Unicamp. In:

CONFERÊNCIA BRASILEIRA DE EDUCAÇÃO, 4,. Goiânia. Anais... Goiânia: [s.n.], 1986. 
BRITO, M. R. F. Acompanhamento e avaliação de um Curso de Formação de Professores de Matemática. In: CONGRESSO ESTADUAL PAULISTA SOBRE FORMAÇÃO DE EDUCADORES, 1, 1990, Águas de São Pedro. Anais... Águas de São Pedro, SP: [s.n.], 1990. p. 49.

BRITO, M. R. F. O ensino superior e a formação do professor: Algumas questões sobre a Licenciatura.. In: ENCONTRO PAULISTA SOBRE FORMAÇÃO DE EDUCADORES, 2, 1992, Águas de São Pedro, SP. Textos do congresso... [s.1.]: [s.n.], 1992. v. 1. p. 52-60.

BRITO, M. R. F.. A psicologia educacional e a formação do professor de matemática, Anais do VI Simpósio da ANPEPP, 1996, Teresópolis, RJ. P.136.

BRITO, M. R. F.. A psicologia educacional e a formação do professorpesquisador: criando situações desafiadoras para a aprendizagem e o ensino da Matemática. Educação Matemática em Revista, São Paulo, SP, ano 9, n. 11, p. 57-68, abr. 2002. (Número Especial)

COELHO, I. M.. Universidade e formação de professores. In: GUIMARÃES, V.S. (Org.). Formar para o mercado ou para a autonomia? O papel da Universidade. Campinas, SP: Papirus, 2006.

DIAS SOBRINHO, J. Universidade e avaliação: entre a ética e o mercado. Florianópolis: Insular, 2002.

DIAS SOBRINHO, J. Dilemas da educação superior no mundo globalizado: sociedade do conhecimento ou economia do conhecimento? São Paulo: Casa do Psicólogo, 2005.

ENADE 2005. Instituto Nacional de Estudos e Pesquisas Educacionais Anísio Teixeira (INEP). Resumo Técnico <http://www.inep.gov.br/ download/enade/2005/Resumo_Tecnico_ENADE_2005.pdf>

FARIA, Paulo Cézar de. A formação do professor de matemática: problemas e perspectivas. 159 p. Dissertação (Mestrado em Educação) - Curso de Pós-Graduação em Educação, Universidade Federal do Paraná, Curitiba, 1996.

FINI, L D.T.; BRITO, M.R.F.; CARVALHO, M.L. Acompanhamento e avaliação dos cursos de licenciaturas da Unicamp: interesse pelo magistério. In: CONGRESSO ESTADUAL PAULISTA SOBRE FORMAÇÃO DE EDUCADORES, 1, 1990, Águas de São Pedro. Anais... Águas de São Pedro, SP: [s.n.], 1990. p. 48.

HAIR, J.F.; Anderson, R. E.; TATHAM, R. L.; BLACK, W. C. 5. ed. Análise multivariada de dados. Porto Alegre: Bookman, 2005. 
LIMANA, A.; BRITO, M. R. O modelo de avaliação dinâmica e o desenvolvimento de competências: algumas considerações a respeito do ENADE. Avaliação, Campinas, SP, RAIES, v. 10, n. 2, p. 9-32, 2005.

MARTINEZ, J. C. M.. Formación del profesorado de secundaria. Estudios Pedagógicos, n. 26, p. 107-117, 2000.

MINISTÉRIO DA EDUCAÇÃO E CULTURA. LEI $n^{\circ} 10.861$, de 14 de Abril de 2004. Instituto Nacional de Estudos e pesquisas Educacionais Anísio Teixeira, INEP. Disponível em: www.inep.gov.br/superior/enade . MINISTÉRIO DA EDUCAÇÃO E CULTURA (2004b). Diretrizes para a Avaliação das Instituições de Educação Superior. Brasília: Instituto Nacional de Estudos e pesquisas Educacionais Anísio Teixeira. 48 p. MINISTÉRIO DA EDUCAÇÃO E CULTURA. SINAES - Sistema Nacional de Avaliação da Educação Superior: da concepção à regulamentação. 2. ed. Brasília: Instituto Nacional de Estudos e Pesquisas Educacionais Anísio Teixeira, 2004c..

NÓVOA, A. formação de professores e profissão docente. In: NÓVOA, A. Os professores e a sua formação. Lisboa: Dom Quixote, 1992. p.13-33. PERRENOUD, P.. Práticas pedagógicas, profissão docente e formação. Perspectivas sociológicas. Lisboa: Dom Quixote, 1993.

POPKEWITZ, T. S.. Profissionalização e formação de professores: algumas notas sobre a sua história, ideologia e potencial. In: NÓVOA, A. (Org.). Os professores e a sua formação. Lisboa: Dom Quixote, 1992. p. 93-114.

RISTOFF, D. I.; GIOLO, J.. O SINAES como sistema. RBPG. Revista Brasileira de Pós Graduação, Brasília, v. 3, n. 6, p. 193-213, CAPES, 2006.

RISTOFF, D. I. Algumas definições de avaliação. Avaliação, Campinas, SP, RAIES, v. 8, n. 2, p. 20-30, jun. 2003.

SECURRO JR., S. Quality of teacher education and nonteacher education graduates: Fact or artifact? Journal of Research and development.

Education, v. 25, n. 3, 1992.

SOUZA, N. A.. Avaliação de Competências: o aperfeiçoamento profissional na área de enfermagem. Estudos em Avaliação Educacional, v. 16, n. 32, p. 57-80, 2005.

VENDRAMINI, C. M. M.. O uso de um modelo multidimensional para análise do ENADE. Avaliação, Campinas, SP, RAIES, v.10, n. 3, p. 27 40, 2005. 